\title{
NIJOLE் ČEPIENÉ
}

Lietuviuc kalbos institutas

Mokslinių tyrimų kryptys: leksikologija, skoliniai, germanizmai, leksikografija, etimologija, kalbos istorija, raštija.

DOI

\section{RELIGINĖ, MITOLOGINE LEKSIKA: SKOLINIAI IŠ GERMANŲ KALBŲ}

\section{Religious, mythological vocabulary: loanwords from Germanic languages}

\section{ANOTACIJA}

Straipsnyje nagrinejjama religijos ir mitologijos teminių grupių germanų kalbų kilmès leksika semantikos ir kilmès aspektais. Skoliniai suskirstyti ị septynis pogrupius: bažnyčios pastatų ir jų dalių, administracijos, aplinkos; bažnyčios vidaus įrangos, vietų joje; apeigu reikmenų, bažnyčios daiktų; švenčių, apeigų; bažnytinès veiklos, knygų, muzikos instrumentų; asmenų pavadinimai; mitologinė leksika, antgamtinių būtybių pavadinimai. Nustatytas germanizmo pamatinis žodis, iš kurio jis kilo, nurodoma skolinio pirminè kilmè. Duodama kitų kalbų atitikmenų. Šalia pateikiamas leksemų fiksavimas raštijoje nuo XVI a. ir vartojimas gyvojoje kalboje, tarmėse. Aptariama skolinių chronologija. Išaiškinta, kad lietuvių olà vartojamas ne tik reikšme 'žvèrelių ar paukščių urvas, landa', kaip pateikiama LKŽe, bet Bretkūno Biblijoje jis užfiksuotas dar reikšme 'patalpa (laidoti), kripta'. Apibūdinami iš germanizmų sudaryti dariniai.

ESMINIAi ŽodŽıAI： religinè, mitologinè leksika, skoliniai, germanizmai, semantika, Prūsijos žodynai, raštija, tarmès.

\section{ANNOTATION}

The article addresses the religious and mythological vocabulary of Germanic origin from the perspective of semantics and origin. Loanwords are divided into seven sub-groups:church buildings and their parts, administration, environment; church interior, places inside it; objects used in rituals, church items; festivals, rituals; church activities, books, musical instruments; names of persons; mythological vocabulary, names of supernatural beings. The base 
word of the Germanism from which it derived is established; the primary origin of the loanword is identified. Equivalents in other languages are presented. The recording of lexemes in the written language dating from the $16^{\text {th }}$ century and their usage in the spoken language and dialects are also provided. The chronology of loanwords is discussed. It was found that Lithuanian olà is not only used in the meaning of 'a cave, burrow of animals or birds' as defined in the Dictionary of the Lithuanian Language but also as 'a chamber (for burial), crypt' according to Bretkūnas' Bible. The formations deriving from Germanisms are described as well.

KEYWORDS: religious, mythological vocabulary, loanwords, Germanisms, semantics, dictionaries of Prussia, written language, dialects.

\section{IVADAS}

Dauguma lietuvių kalbos skolinių iš germanų kalbų, daugiausia vokiečių kalbos, yra materialiosios kultūros žodžiai. Tačiau turima ir nematerialiosios kultūros germanų kilmès ar atejjusių iš germanų kalbų žodžių, nors ir jie dažnai įvardija materialius daiktus. Religijos ir mitologijos teminės grupès skoliniai užfiksuoti jau pirmuosiuose XVI a. raštuose, daugiau Prūsijos. Medžiaga straipsniui rinkta iš lietuvių kalbos senųių raštų, vèlesnių darbų, Prūsijos lietuvių-vokiečių ir vokiečių-lietuvių žodynų, taip pat iš gyvosios kalbos, tarminių tekstų, šnektų ir tarmių žodynų bei dabartinès bendrinės kalbos. Jame panaudota Lietuvių kalbos žodyno I-XX t. (LKŽ, LKŽe) ir kitų darbų medžiaga (žr. literatūros ir šaltinių sąrašą). Straipsnio tikslas - pateikti ir panagrinèti germanų kalbų kilmès religinę, mitologinę leksiką semantikos, kilmės, chronologijos aspektais, paaiškinti skolinio pirminę kilmę; nurodyti leksemų fiksavimą raštijoje ir vartojimą gyvojoje kalboje, tarmèse; pateikti iš religinès leksikos germanizmų sudarytų darinių. Darbe pateikiami germanų kalbų, daugiausia vokiečių kalbos, kilmès žodžiai, tiesiogiai patekę ị lietuvių kalbą; germanų kalbų kilmès žodžiai, galëję patekti ị lietuvių kalbą iš kitų kalbų tarpininkių, daugiausia slavų kalbų; ne germanų kalbų pirminès kilmès žodžiai, bet pasiskolinti iš germanų kalbų.

Naujesniuose religinės leksikos, religijos terminų tyrinejjimuose užfiksuota nedaug germanizmų. Algis Rubinas daktaro disertacijos Lietuviu kalbos religine leksika ir jos istorija (2002) skyriuje Lietuviu kalbos germanizmai pateikè tik tris germanizmus: kùnigas 'dvasininkas, klebonas', põde 'krikštamotè', agenda 'maldų knyga, ritualas'. Skyriuje Lietuviu kalbos slavizmai randami dar keli skoliniai, autoriaus manymu, atėję per vokiečių kalbą: kardinolius, abtas (aptas) 'vyrų katalikų vienuolyno viršininkas', kapucyneris 'pranciškonų ordino vienuolis', keceris 'eretikas, atskalūnas'. 2012 m. Aušros Rimkutès daktaro disertacijoje 1883-1916 metu katekizmu religijos terminai yra taip pat nedaug vokietybių: kunigas, gizelis 'mokinys', pode, pl. podžiai 'krikšto tèvai', katgismas 
'katekizmas', vediniai: kunigystè, kunigaikštystè. Šio straipsnio autorè raštuose, žodynuose, tarmèse rado daugiau religinès leksikos žodžių, kilusių iš germanų kalbų, daugiausia vokiečių kalbos, ar patekusių ị lietuvių kalbą iš germanų kalbų, kurie čia bus apžvelgiami. Straipsnyje taikomi diachroniniai ir sinchroniniai tyrimo metodai: lyginamasis istorinis, gretinamasis, fonetinis ir kiti, remiamasi etimologiniais žodynais, naujausiais kalbotyros darbais.

\section{GERMANŲ KILMĖS RELIGINĖS, MITOLOGINESS LEKSIKOS SEMANTIKA, KILMĖ, PAPLITIMAS IR VARTOJIMAS}

Raštijoje nuo XVI a. (daugiausia Prūsijos, Mažosios Lietuvos) ir tarmėse užfiksuota germanų kilmès ar pasiskolinta iš germanų kalbų religinès teminès grupés leksika suskirstyta ị šešis pogrupius, septintajame pateikta mitologinè leksika. Daugiausia šios teminès grupès germanizmų rasta XVII-XX a. Prūsijoje leistuose vokiečių-lietuvių ir lietuvių-vokiečių žodynuose: Lexicon $\mathrm{Li}$ thuanicum, Clavis Germanico-Lithvana, buvusio Karaliaučiaus archyvo rankraštiniame (vadinamame A. Krauzès) žodyne, Jokūbo Brodovskio Lexicon Germanico-Lithvanicvm et Lithvanico-Germanicvm, Pilypo Ruigio LittauischDeutsches und Deutsch-Littauisches Lexicon, Christiano Gottliebo Mielckès Littauisch-deutsches und Deutsch-littauisches Wörter-Buch, G. H. F. Nesselmanno Wörterbuch der Littauischen Sprache, Friedricho Kuršaičio Littauisch-deutsches Wörterbuch ir Deutsch-littauisches Wörterbuch, Aleksandro Kuršaičio Lietuviškai-vokiškame žodyne. Germanizmai nagrinèjami abėceline tvarka. Šalia skolinio nurodomi duomenų laukai: gramatinès pažymos, reikšmès, fiksavimas šaltiniuose, paplitimas tarmèse, kilmé; pateikiami germanų kilmès pamatiniai žodžiai, iš kurių skoliniai yra kilę, aiškinama pirminè žodžio kilmė, duodama kitų Europos kalbų atitikmenų; pateikiamos kitų tyrejuc etimologijos.

1) bažnyčios pastatų ir jų dalių, administracijos, aplinkos pavadinimai, pvz.:

aptija sf. 'katalikų vienuolynas su jam priklausančiomis valdomis' Lex 3a, C I 43 (orig. Aptye), Q 13, K I 32, Alm 27; abtìja N 2 (abtije), Alm 23 < v.v.a. abbeteie (eppetige); abbetīe; plg. v.v. ebedîe, Pr.v. Abtey (Lex 3a), n.v.a. Abtei f. 'abatija, vienuolynas'; s.v.a. abbateia iš bažn.lot. abbātia (Kluge 2002: 11; Lexer I 1; PaulW 11).

domskirchė sf. 'katedros bažnyčia' S. Dauk < n.v.a. Domkirche 't. p.'

dreskamara sf. 'zakristija' B 361, 1033 (orig. Drezkamara), MŽ II 135, 398, N 155; dréskamarè sf. (1) K, Prel 56 (dréskamare), Alm 45, KŽ, Skr; 
dryskamarė sf. LC 1885, 12 < Pr.v. Drêskammer 'zakristija, kurioje saugomas bažnyčios turtas, pinigai, vertingi ịrankiai’ (Fr I 150, Ziesemer II 107), v.v.a. trëse-kamere f. (dresekamer, dryskamer), s.s. tresocamara (Lexer II 1505; Grimm XXII 163); plg. Baltijos vok. Drähskammer 't. p.', v.ž. drēskammer 'zakristija' (Sehwers 1953: 28, 326); vok. Dresekammer, tresekammer f., trisekammer 'bažnyčios iždine, lobynas; archyvas; zakristija (nuo XV a. pab.)', s.v.a. tresecamere, dresecamere, v.v.ž. tresekamere f., v.nl. trescamere; dūrinys iš tresso < lot.-rom. thesaurum ir lot.-rom. camara, camera (Grimm XXII 163; MndW IV 611-612). gemýnė sf. (1) 'apylinkė; bažn. parapija' N 249, [K], KŽ, gemyne Alm 53, gemyna sf. LC 1878, 42; gimýna sf. (1) 'valsčius; parapija' K, Alm 54, KŽ < Pr.v. gemêne 'bendruomenè; parapija' (Alm (PrW)) dialektizmo; plg. v.v.ž. gemeine, gemene f., n. 'bendras turtas; bendruomenès susirinkimas; (kaimo, parapijos ir kt.) bendruomenë' (MndW II 53), v.v.a. ge-meinde f. 'bendrumas; bendruomenè', s.v.a. gimeinida, n.v.a. Gemeinde f. 'bendruomené; bažn. parapija', $\rightarrow$ vok. adj. gemein 'bendras' (Kluge 2002: 343; Lexer I 839); 1. gmina 'bendruomenè' iš vok. gemein, Gemein(d)e (Brückner 1974: 146).

kapelè sf. 'maža bažnytėlè, koplytèlè' B 795 < v.v.a. kappëlle, kapëlle, kappel f. 'maža bažnyčia, Dievo namai', n.v.a. Kapelle f. 'koplyčia, koplytėlë'; vok. iš v.lot. capella 'koplyčia'; plg. n.nl. kapel (Lexer I 1514; Kluge 2002: 468).

kir̃ kapis (hibr.) sm. (1) 'kapai prie kirkès; šventorius' R I 54, R II 223, MŽ II 298, N 200, K, KŽ, Alm 66, kirkkapis KŽz; dūrinys iš germ. kirkè ir liet. kapas; plg. n.v.a. Kirchhof m. 'kapai, kapinès'.

kìrkè sf. (1) 'protestantu bažnyčia' NdŽ, BM 177 (Bažnyčios yra trys: bažnyčia katalikų, žydu šule ir latviu kirkè), Š, KŽ, KrtnŽ, FrnW, Srj, kiřke (2) ZŠŽ $(\mathrm{Nm})$; kirche Š, kìrka sf. (1) 'protestantų bažnyčia' M. Valanč, M, rš, KŽ, ZtŽ < v.v.ž. kerke f. 'bažnyčia' (MndW II 449; Lasch 1914: 51), v.v.a. kirche f. '(krikščionių) bažnyčia, pastatas; žydų šventykla; tikinčiųjų draugija', n.v.a. Kirche f. 'bažnyčia'; plg. n.norv. kirke, n.šv. kyrka, s.fryz. kerke, s.s. kirika, n.nl. kerk; vok. iš vulg. gr. *kyrikế (Lexer I 1580; Kluge 2002: 489).

klosteris sm. 'vienuolynas' B 313; klostorius (klostorus) Lex 21a (orig. Kloftorus), 54a (Kloftorus), C I 1079 (Klóftorus) < Pr.v. Klofter (Lex 21a), v.v.a. klôster n., n.v.a. Kloster n. 'vienuolynas'; plg. v.v.ž. klōster-, v.nl. clooster, n.nl. klooster, s.v.a. klōstar; vok. pasiskolino iš ankstyv. romanų *clōstrum 'užsidaręs', lot. claustrum 'užraktas, uždarymas; pilis' (Kluge 2002: 499; Lexer I 1631).

kodryna sf. 'bažnyčios bokšto vèliava' C I 649, N 203, [K]; plg. Pr.v. Kodder 'skuduras, skarmalai; blogi, suplyšę drabužiai' (Fr I 399), Koder 'skuduras, skarmalai, skiautè' (Grimm XI 1569).

kõras (kòras) sm. 1. 'bokštas, varpinè' NT Mt 21,33, B 190, R I 65 (Kôras), R II 180, MŽ I 127, N 205 (Kóras), K (ir kúras), KlvD 115, J, V. Kudir, dem. 
koratis N 205. 2. 'bažnyčios prieangis' R II 91 (Kóras), MŽ II 120; kuõras ${ }^{1}$ sm. 1. 'bokštas, varpinè' SD 7, SD³ 8, R I 71 (orig. Kůras), N 205, K, J, Vaižg, FrnW, V. Krèv, rš, Pnm, Čk, Klt, dem. kuorelis NS 1157, kuoratis RD 35. 2. 'bažnyčios bokšto vẻliava' Lex 34 (orig. Kûras), C I 628 (Kůras), Q 173, B 444 (Kůras); < Pr.v. kor, kur, kûr 'choras; paaukštinta vieta bažnyčioje chorui, viškos' (Alm (PrW)), kūar (Natau 1937: 18), v.v.a. kôr, kur m. 'bažnyčios choras, giedotojai chore; katedros kapitelis; perk. dangaus skliautas; vieta danguje kaip Dievo buveinė; angelų sfera' (Lexer I 1678; Grimm XI 1792), v.v.ž. kôr (Lasch 1914: 95), n.v.a. Chor m. 'grupe giedotojų; krikščionių bažnyčiose giedotojų vieta prieš altorių; pakyla, scena (protestantų bažnyčiose)'; plg. n.nl. koor; s.v.a. chōr iš lot. chorus 'šokis su dainomis, ratelis; būrys, pulkas, daugybè', o šis iš gr. chorós 'vieta šokiui; grupe šokejjų; kulto giesmè ar kulto šokis Dievybèms' (Kluge 2002: 171; LLŽ); v.v.ž. kur(e) 'sargybinis, žvalgas (bokšte)', kuren 'sekant žiūrèti (medžiotoju terminas)' (MndW II 602). Plg. dar 2) kūras.

kunzistórija sf. (1) 'centrinè vadovaujanti bažnytinė valdymo įstaiga' K I 703, Alm 76 < n.v.a. Konsistorium n. 't. p.' dialektizmo; plg. lot. consistorium 'pasitarimo, susirinkimo vieta'.

olà sf.'urvas, patalpa (laidoti), kripta' žr. prie 3 .

tur̃ mas ${ }^{2}$ sm. (2) 'bokštas, varpinė; gyvenvietė (apie piliakalnį)' BB $1 \mathrm{Moz}$ 11,4, BB 2 Kar 9,17, BB Teis 9,46, BB 1 Mak 4,60 (acc. pl. Thurmus), BB 2 Krn 26,9, BB 2 Mak 13,5, BB Jdt 1,3, BB Ez 26,4, BB Jer 51,58, BB GG 4,4, BB Bar 6,17, BB Luk 14,28, BB Ezd 3,1, Lex 87a, RB Ps 48,13, C II 583, Q 523, H I 135, H II 211, K, K II 228, Mit V 151, J, Kel, Dor (Klp, orig. tórms), NdŽ, ALL 54, 35 (NTK), Alm 144, KŽ, Smln, Ser; stur̃nis sm. (2) 'varpinë' K I 555, KŽ < Pr.v. Turm 'miesto kalejjimas; bokštas' (Fr II 416), Thurm (Lex 87a), tộm 'bokštas, kalejjimas' (Alm 144), Ryt. Pr.v. torəm (Mitzka 1919: 126), v.v. turm, torm, v.v.a. turn, turm, sturm; vok. Turm, Thurm 'bokštas, varpiné; įtvirtinimas; kalejiimas' iš turrem, o šis iš s.pranc. *torn; pastarasis iš lot. turris f. 'bokštas, pilis,

${ }^{1}$ W. Smoczyńskis kuõras laiko neaiškiu žodžiu (Smoczyński 2007: 326). Kuõras reikšmę 'dešimties pèdų guba, rikè' LKA I 186, žemèl. 109, Trgn, Slk, Lb, Ign, Švnč, Dglš, Lkm, Klt, dem. pl. kuorêliai Pls galbūt reikètų sieti su vok. kar 'indas, dubuo; javų matas; aukštas (namo); viena ant kitos sudètos dèžès; pašiūrè, stoginė; sunešta šieno ar šiaudų krūva'; plg. s.s. kar, v.v.a. kar, n.v.a. Kar n., dan. kar, šv. kar (Grimm XI 202); v.v.ž. kar, kare n. 'indas, krepšys' (MndW II 428), senas keliaujantis žodis (Kluge 2002: 470). J. Brodovskio žodyne užfiksuotas iš Biblijos vok. Cor (menfura) '(javų) matas' išverstas liet. Korras (B 315).

2 Pilies ir miesto bokštų apatiniai aukštai buvo naudojami kalejjimams. Todèl šis žodis vartojamas dar reikšme 'kalèjimas' BB ApD 5,20, BB Jon 3,24, VlnE 43,5 (loc. pl. turmůfu), VlnE 202,19, VlnE 205,25, ŽCh 71, Lex 87a, R II 162, 351, MŽ II 214, 470, N 110, K, S. Dauk, M, J I 149, L, JD 201, KlvD 144 (Vlkš), BsO 397, BsMt II 166 (Dkš), Sln, Alm 144, LTR (Zp), LTs V 583, KŽ (A 1883, 226), DrskŽ, ZŠŽ, Als, Žg, Ūd, Vl. 
aukštas pastatas'; plg. n.šv. torn, n.isl. turn (Grimm XXI 466; Lexer II 1582; Kluge 1957: 798; 2002: 936); v.v.ž. torn, s.s. turn 'bokštas; kalejjimas' (MndW IV 580); la. tuõrnis (Tuhrnis, Turrnis) 'bokštas' iš v.v.ž. torn, torne, turn 't. p.' (Sehwers 1953: 146, 324); (v.1.) n.l. turma 'bokštas (naudojamas kalèjimo reikmėms); kalëjimas; pančiai, našta; toks žaidimas' < v.v.a. turm 'bokštas'; s.brus. турма 'kalèjimas', n.brus. (dial.) турмá 't. p.' (Brückner 1974: 585; LKPŽ 656).

2) bažnyčios vidaus įrangos, vietu joje pavadinimai, pvz.:

gángos sf. pl. (1) 'bažnyčioje vieta prie vargonų; viškos' C II 752, K, K I 369, K II 102, Alm 52, FrnW, KŽ; gángai sm. pl. NmŽ < Pr.v. Gang 'laiptai' (R II 157), n.v.a. Gang m. 'èjimas, eisena; èjimo vieta, praèjimas, koridorius; kelias, viškos (bažnyčioje), pakyla’; plg. v.v.a. ganc m. 'ejjimas; kelias', s.v.a. gang, s.s. gang, s.ang. gang, s.skand. gangr m., ganga f., s.fryz. gang, gong, gung, šv. dial. ganga, n.nl. gang (Kluge 2002: 329; Lexer I 734; Grimm IV 1219).

kúras sm. (1) (kuras) 1. 'pakyla, paaukštinta vieta bažnyčioje chorui, kur yra vargonai, viškos' Lex 20a (orig. Kuras), C I 428, B 302, 311 (kuras), K 197 (kúras), K II 102; pl. k kũrai (2) Vdk, Žgč, Nmk, Kltn; kùras (kuras) '(vargonų) choras' Lex 21a, C I 428, Q 110, B 312, Alm 76, 'būrys, pulkas (angelų)' C I 428, 'laiptai' C I 428; kõras sm. 1. 'paaukštinta vieta bažnyčioje chorui, viškos' B 311, I. Simon, Prk. 2. 'choras, grupe giedotojų' B 311, NdŽ; kòras (2) LzŽ, kóras (1) Alm 70. 3. 'balsas, tonas (tik Biblijoje)' Bb ${ }^{1}$ Ps 120,1, B 698 (orig. Dangaus Kóras); kuõras (4) 'choras; būrys, pulkas (apaštalų, angelų)' DK 30 (orig. nom. pl. kůrái), 37, 148, DP 38, 543, R I 71 (orig. Kưras), VoK 11, KrtnŽ (kûors), ŠVŽŽ (kûors Vin, Kra, Meds, Žbr); < Pr.v. kor, kur, kûr 'paaukštinta vieta bažnyčioje chorui, viškos; choras' (Alm (PrW)), v.v.a. kôr m. 'bažnyčios choras; giedotojų būrys; vieta maldos namuose, kurioje būna giedantys dvasiškiai' (Lexer I 1678), n.v.a. Chor m. 'dainininkai, giedotojai, dainavimas, giedojimas; ratas, būrys, pulkas; krikščionių bažnyčioje giedotojų vieta prieš altorių, protestantų bažnyčiose pakyla, viškos, kur giedama ir muzikuojama'; plg. s.v.a. chōr 'dvasininkų choras bažnyčioje', n.nl. koor; lot. chorus; gr. ұopós; iš reikšmès 'giedotojas' krikščionių bažnyčioje kilo reikšmè 'giedotojų vieta prieš altorių', iš čia 'vieta bažnyčioje, skirta dvasininkams' (Kluge 1957: 117; 2002: 171), v.v.ž. kôr (Lasch 1914: 95); la. kuõris iš vok. (Sehwers 1953: 61); 1. chór 'choras; galerija' iš gr., lot. choros, chorus (Brückner 1974: 182). Plg. 1) koras.

3) apeigų reikmenų, bažnyčios daiktų pavadinimai, pvz.:

ablótas sm. 'kaleddaitis, plonas paplotẻlis, iškeptas iš miltu ir vandens' Q 372 (orig. Ablots), R II 210, MŽ II 368, N 2, 30, [K], K II 98, Alm 23 < Pr.v. Ablatt 't. p.' (Fr I 8; Alm 23); plg. Oblat (C II 161), v.v.a. oblâte, oblât f., n. 'komunijos 
paplotèlis, ostija', n.nl. oblaat, n.v.a. Oblate f., v.lot. oblata (hostia) (Lexer II 138; Kluge 2002: 661). Plg. dar oblotas.

bikierelis sm. dem. 'kaušelis, taurelë' SD 116, SD $3134<$ s.s. bikeri, s.v.ž. bikeri; plg. v.ang. biker, v.v.a. becher m. 'tauré; kaip matas', Ryt. Pr.v. bēkəř ‘taurè', n.v.a. Becher m., n.nl. beker; vok. iš v.lot. bicarium n. 'indas vynui, vandeniui, tauré' (Kluge 2002: 99; Lexer I 137; Mitzka 1919: 122); la. bikgeris iš s.v.ž. bikeri (Sehwers 1953: 12, 326); 1. becher (bekier), dem. becherek. Urbutis liet. dem. bikerèlis iš *bikeris kartu su la. bikgeris laiko tiesioginiu germanizmu (Urbutis 2009: 418). ALEW liet. bikierelis kildinamas iš 1 . becherek, kuris per vok. pasiskolintas iš lot. (ALEW I 113).

isopas sm. bot. 'vaistinis juozapas, yzopas (Hysopus officinalis), jo sultys; yzopo šakelès bažnyčioje naudojamos kaip šlakstyklë' Mž 358,5, BB 2 Moz 12,22, BB $3 \mathrm{Moz}$ 14,4, BB $4 \mathrm{Moz}$ 19,18, VlnE 210,12 (orig. instr. sing. Ifopu), R II 217, rš, P, TA 417 (Issopas), BzF 118; hysopas Mž 538,19 (instr. sing. hyfopu); yzopas Vln ${ }^{1}$ 175, Lex 52a, C I 416, 1023, C II 249, 1025, RB Ps 51,8,

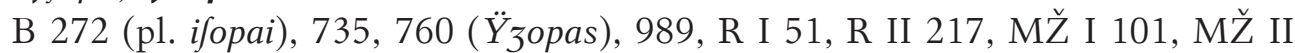
288, NT PvŽ 9,19, NT Jn 13,29, K (ýzopas), NdŽ, P, TA 417 (Yzopas), BzF 118, Alm 57, LBŽ; ìzopas (1) NdŽ < Pr.v. Ifop 'vaistinis juozapas' (Lex 52a; C

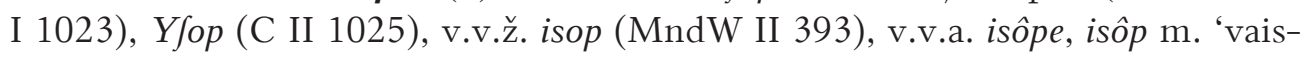
tinis juozapas' (Lexer I 1459), n.v.a. Ysop, Hysop m. (f.), Isop 'mažas krūmas su labai kvepiančiais lapais ir violetiniais žiedais (Hyssopus officinalis L)'; plg. ags. ysope f., s.v.a. hyssop m., vèlyv. s.v.a. - ankstyv. n.v.a. yzopus f.; lot. hyssōpus f., hyssōpum n. (Grimm XXX 2575).

kelichas sm. '(liturginè) taurè' BB Ps 23,5, BB Ez 23,31, BP I 366, BzB 294 < v.v.a. kelich, kelch m. 'taure'; plg. s.v.a. kelih, s.s. kelik, n.v.a. Kelch m. 'taurë'; vok. iš lot. calix 'taurè' (Lexer I 1539; Kluge 2002: 483), v.v.ž. kelk, kellik m. 'taurè' (MndW II 440); (s.1., v.1.) n.1. kielich 'indas, naudojamas apeigoms krikščionių bažnyčioje; taure ir kt.' < v.v.a. kelch, s.v.a. kelih, n.v.a. Kelch 't. p.', iš lot. calix 'taurè, dubuo'; s.brus. келикъ (килихъ) '(aukojimo) taurė; simbolinis likimo įvardijimas', n.brus. ке́лихъ, ке́лix 'didelè, aukšta taurè’ (LKPŽ 372). Plg. dar kylikas.

kylìkas (kilikas, kylỹkas K) sm. (2) K '(liturginè) taurè’ Mž 143, 380, 534 (kilikas), BP I 62, Vln 33,10, Vln 35, Vln 65,23, Vln ${ }^{1} 36, \mathrm{~V} \ln E$ 164,23, VlnE 172, VlnE 190,2 (Kilikas), Lex 53a (kilikas), C I 1050, Q 293 (kilikas), B 341, 566, 655, 776, H 55, R I 72, MŽ I 139, N 199, K II 223, KŽ, Alm 66 (kylikas), Rg, Kč (kilikas (1)); kilichas sm. RB 116, kylichas Alm 66; < v.v. kilich m. 'taurè'; plg. v.v.a. kelch, kelich m. (Lexer I 1539), s.s. kẹlik, s.v.a. kẹlich (Kluge 1957: 362); v.v.ž. kellik m. 'gèrimo indas, taurè' (MndW II 440), n.v.a. Kelch m. 'taurë'; vok. iš lot. calix 'taurë'; ịvedus krikščionybę, pirmiausia vartojamas tik 
reikšme 'religinių apeigų taurè' (Grimm XI 504); la. ķelliks 'indas' iš v.ž. kellik 'indas gerti, taurè' (Sehwers 1953: 63). Plg. dar kelichas.

klingbidelis sm. 'maišelis pinigams bažnyčioje rinkti' B 802, 1032 < Pr.v.ž. Klingbüdel 'piniginè, maišelis su skambučiu ant lazdos rinkti išmaldai pamaldu metu' (Fr I 378); vietoje vok. ü jau Prūsijos vokiečių tarmèje buvo tariamas garsas $i$ (̌̌r. Čepienè 2006: 211); plg. n.v.a. Klingelbeutel m. 'krepšis su varpeliu ant ilgos lazdos, naudojamas pamaldų metu aukoms rinkti'.

kozoliai sm. pl. 'kunigo apeiginis drabužis, kamža' Q $110<$ Pr.v. Kâsel 'pamaldų apdaras, choro marškiniai; platus apsiaustas, patogus švarkas, senas, mielas drabužis; ilgas sijonas iš tankios drobės su gobtuvu' (Fr I 343); plg. 1. koszula 'marškiniai; abitas, vienuolių drabužis; bažn. arnotas, viršutinis kunigo apdaras, dèvimas per mišias' iš lot. casula 'paltas su gobtuvu'.

mìras (myras) sm. 'kvapūs sakai, esantys kai kurių Afrikos ir Arabijos medžių žieveje, vartojami smilkalams’ Mž 195, BB 1 Moz 37,25, BB SalK 7,17, BB GG 5,1 (orig. acc. sing. mÿrrha), BB Sir 24,1, BB Est 2,2, BB Ps 45,9 (myras), RB Ps 45,9, B 235 (pl. Myrrai), BsMt I 29; miré sf. R I 88 (mirré), MŽ I 170, N 403, K, Alm 87 (mirrè), FrnW; plg. Pr.v. Mîre, Myrrhen (C II 96), Myrrhe (Lex 63), v.v.ž. mirre '(karčioji) mira' (MndW III 95), v.v.a. mirre, mirr m. 'mira' iš arabų mirren (Lexer I 2158), s.v.a. mirra, myrra, s.s. myrra, ags. myrre, n.nl. mirre, n.šv. myrra, n.v.a. Myrrhe f. 'mira (sakai)'; vok. iš lot. murra, myrrha, o šis iš gr. mýrrha f., mýrra; semitų kilmès žodis; arabų murra sietina su šaknimi marru ‘būti karčiam'; i germanų kalbas pateko per Bibliją (Kluge 1957: 497; 2002: 641); 1. mira. E. Fraenkelis, remdamasis P. Skardžiumi, liet. mirà laiko skoliniu iš lenkų kalbos (FrnW).

oblótas sm. (1) 'komunijos paplotèlis' C II 161, B 727 (orig. Oblot's), B 956 (oblotas), N 30, [K], Alm 93 < Pr.v. Oblat 't. p.' (C II 161), v.v.a. oblâte, oblât f., n. (oflôte) 'komunijos paplotėlis; kepinio rūšis'; plg. n.v.a. Oblate f. 'plonas iš miltu ir vandens iškeptas paplotis; bažn. komunijos paplotėlis', s.v.a. oblāta, ovelāta, n.nl. oblaat, n.šv. oblat; vok. iš v.lot. oblata (hostia) 't. p.' (Lexer II 138; Kluge 2002: 661). Plg. dar ablotas.

skrỹnè sf. (2), skrynẽ (4) 1. 'katalikų bažnyčioje puošni spintelè altoriaus viduryje ostijai laikyti' BB 2 Mak 2,5, BB 2 Krn 31,11. 2. 'aukų dèžè, kasa' BB Luk 21,2, VlnE 199, Lex 43a (orig. Diewa Jkrine), H 181, B 596, K I 93, 678, TP 1881, 9, LC 1878, 21, dem. skrynele I. 3. 'laivas (apie biblinio Nojaus įrengtą laivą)' BB 1 Moz 6,14, B $117 \diamond$ suderëjimo skrynè bažn. 'sandoros skrynia' BB Teis 20,27, BB Joz 4,18, C I 1142 (orig. Skryne Suderejimô), B 302, 833, R I 134, MŽ I 246, dem. skrynele liudijimo (orig. Skrinele Liudimo) 'sandoros skrynia' BB 2 Moz 26,33); < v.v.ž. schrîn 'skrynia, dèžè; karstas' (MndW IV 138); v.v.a. schrîn m., n. 'skrynia, dèžè drabužiams, pinigams, brangenybèms, relikvijoms; karstas' (Lexer II 799), v.nl. scrīne; plg. s.v.a. scrīn(i), s.ang. scrīn, s.fryz. skrīn, 
ags. scrīn 'dèžè, lagaminas, narvas, dèžutè vertingiems daiktams, brangenybėms, relikvijoms', ang. shrine 'dèžè; altorius; šventovè', n.šv. skrin, n.v.a. Schrein m. 'puošni dèžè kulto daiktams, relikvijoms saugoti; karstas; skrynia; spinta'; vok. iš lot. scrīnium 'apvalus indas kam nors laikyti' (Kluge 1957: 679-680; 2002: 826; Grimm XV 1725); la. skrìne, skrinnis 'dèžè, skrynia (drabužiams, miltams); spinta' iš v.v.ž. schrīn 'spinta; skrynia; dèžè; stalčius' (Sehwers 1953: 106; Karulis II 206) ar v.ol. schrijn, schrine 'dèžè, skrynia; stalčius' (Karulis II 206); (s.l., v.1.) n.1. skrzynia 'užvožiama dèžè; skrynia ir kt.' < s.ček. škřině 'spinta; dèžè', iš v.v.a. schrîn, s.v.a. scrîni, skrîni 'dèžé; spinta', iš lot. scrīnium 'apvalaina dèžè saugoti knygoms, dokumentams'; s.brus. скрыня, скриня 'dèžé; stačiakampio formos talpykla; slèptuvè; karstas'; n.brus. (dial.) скрыня 'didelè dèžé; skiaurẻ (dėžè su skylutėmis gyvoms žuvims laikyti); dèžè miltams, grūdams laikyti; èdžios'; s.rus. скрьнна 'kaustyta dèžè, skrynia; dèžè su dangčiu', n.rus. скрьня 'dèžè, užvožiama dèželè' (LKPŽ 581-582). P. Skardžius lietuvių skrynià, skrỹnè laiko skoliniais iš brus. скрьня ar 1. skrzynia (Skardžius 1931: 199), о W. Smoczyńskis kildina iš brus. skrýnja (Smoczyński 2007: 567). Šio darbo autorè mano, kad lietuvių skryné kartu su latviu skrine galètų būti pasiskolinti iš vidurinès vokiečių žemaičių tarmès schrīn 'dèžè, skrynia, spinta, stalčius'. Dẻl priebalsių junginio sk žr. Čepienè 2006: 291-292.

tapelis sm. 'maišelis su skambučiu aukoms bažnyčioje rinkti' Q 478, N 89, [K], BzF 189 (orig. tåpel'), BS 146, Alm 141, FrnW, KŽ; plg. Pr.v. tofel 'plokštė' (Alm (PrW)), n.v.a. Tafel f. 'lenta; plytelè; plokštè'. Plg. dar tobelis.

tõbelis $\mathrm{sm}$. (1) 1. 'maišelis su skambučiu aukoms bažnyčioje rinkti (Klingsäckel)' N 107 (Klp), Fr II 403, K, Alm 142, KŽ, Klp. 2. (pa)tobelis 'bažnyčios tarnas, kuris kaip vertejas stovejo po lenta' FrnW $\rightarrow$ patobelis $<$ Pr.v. Potabel 'anksčiau [Prūsų] Lietuvoje bažnyčios tarnas, padedantis vokiečių bažnyčios tarnams. Ju tarnyba - skambinti varpais, parūpinti vyno ir komunijos paplotèlių, tvarkyti bažnyčią ir jos įrankius ir kt.' (Fr II 172); plg. patobelis 'bažnyčios patarnautojas, kuris stovejo už lentos, vok. Tafel, kaip vertèjas' (R I 162, MŽ I 296, Alm 97), Pr.v. tôfel 'lentelè, plokštè' (Alm 142), n.v.a. Tafel, Elzaso dial. tôfel '(pakabinta) plokštè, lenta, mušama išgauti garsui, duoti ženklą, naudojama bažnyčiose, vienuolynuose vietoje skambinimo' (Grimm XXI 13), Pr.v. Tobolize f. 'kišenè, krepšelis' (Fr II 403); 1. toboła '(kelioninis) krepšys, kuprinè, maišelis' (Brückner 1974: 572), tobót. Plg. dar tapelis.

4) švenčių, apeigu pavadinimai, pvz.:

bèrès sf. pl. 'laidotuvių vaišès, šermenys' BzF 99, LTR, KŽ < Pr.v. Behre 'puota dailidèms' (Ziesemer I 530); plg. v.v.ž. böre 'neštuvai'; bore (MndW I

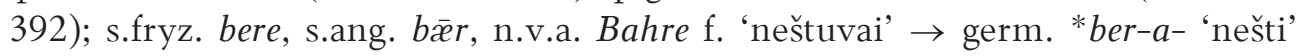
(Kluge 2002: 83); la. bẽres '(laidotuvių) neštuvai' iš v.v.ž. (Sehwers 1953: 11). 
ĩlgès sf. pl. (2), ìlgès (1) 1. 'Visų Šventųių šventè (lapkričio 1 d.)' nuo XVII a. Mažosios Lietuvos žodynuose (Lex 5, orig. Ilges), C I 66, Q 21, B 66, R I 48, MŽ I 96, N 25, [K]), kituose darbuose (JD 210, Mit I 239, Alm 56, FrnW, BŽ 507, KŽ (A 1885, 307)), On. 2. 'Vèlinès, Vèlių diena (lapkričio 2 d.)' S. Dauk; $<$ v.v.ž. hilgen 'šventieji' (Sehwers 1953: 41), v.v.ž. hilligen, de hilgen 'šventieji' (Alm 56); plg. v.v.ž. adj. hillich 'šventas (asmenys ir daiktai)', de hilge geist 'Šventoji Dvasia' (MndW II 266-267), n.v.a. heiligen 'šventieji', Pr.v. Allerheilig[en] fest 'ilgès, Visų Šventųiu šventè' (Lex 5); la. ilges, ilgi 'Visi Šventieji' iš v.v.ž. (Sehwers 1953: 41).

ilgikristis sm. (2) 'Kūčios (?)' K I 684³, KŽ, pl. 'Kūčiu dovanos' KŽ; dūrinys iš v.v.ž. hilgen 'šventieji' ir liet. Kristus, plg. n.v.a. der heilige Christabend.

kirvelis sm. 'parapijinè švente (minint bažnyčios pašventinimą); muge (ryšium su parapijine švente)' KŽ; plg. Pr.v. Kirms, Kirmes, trumpiniai iš vok. Kirchmesse, tarm. 'bažnytinès šventės puota', Kirmas 'mugè' (Fr I 356), franku kerwa (Grimm XI 835), n.v.a. Kirmes f., v.v.a. kirch-mësse f. (kirmess, kirmes) 'pamaldos, skirtos bažnyčios pašventinimui; mugè', n.nl. kermis, n.ang. (dial.) kermis, n.pranc. kermesse; vok. Kirmes tikriausiai iš nepaliudyto ${ }^{*}$ Kirchweihmesse (Lexer I 1585; Kluge 2002: 490).

liktìs sf. 'Grabnyčiu šventė; pamaldos, į kurias tikintieji eina su žvakėmis (vasario 2 d.)' K (Kt), Alm 80, KŽ; liktis sm. N 365 (Tlž), [K] < Pr.v. licht 'žvakè, šviesa' (Alm (PrW)), n.v.a. Licht n. 'šviesa; žiburys; žvakė; Dievas ir Kristus'; plg. v.v.a. adj., s. lieht, v.v. liecht; lîcht n. 'šviesa; švytèjimas, žibèjimas; žvake’; v.v.ž. licht, lecht n. 'šviesa'; $\rightarrow$ vok. adj. licht 'šviesus, skaistus', verb. leuchten 'švytėti, žibèti, šviesti, spindèti, žybsèti' (Lexer I 1906; MndW II 684; Kluge 2002: 574).

liktmušès sf. pl. 'tokia krikščionių šventè (vasario 2 d.)' B 466 (orig. Likt-

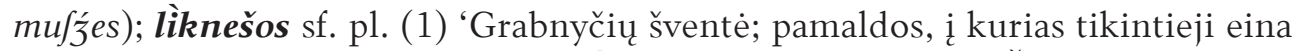
su žvakemis' K, LsB 199, Alm 79; lìktnešos sm. pl. (1) K, KŽ, Alm 79 < Pr.v. lixtmes 't. p.' (Alm (PrW)), dèl liaudies etimologijos priderinta prie liet. liktìs nešti (Alm 80); plg. n.v.a. Lichtmesse, Lichtmeß f. 'Marijos apvalymo šventè (vasario 2 d.), taip pavadinta dèl tą dieną šventinamų žvakių' (PaulW 375), v.v.a. lieht-mësse f. 't. p.' (Lexer I 1909); germ. liktis ir liet. nešti.

5) bažnytinès veiklos, knygų, muzikos instrumentų ir kt. pavadinimai, pvz.: agenda sf. 'maldų knyga, ritualas' DP 456,7, ageñdos sf. pl. (2) K I 43, Alm 23; plg. n.v.a. Agende 't. p.', n.nl. agenda, lot. agenda (Kluge 2002: 20).

almusina sf. 'išmalda, dovana' Lex 5 (orig. almufina), Q 22 (Almufina); alamusýna sf. (1) C I 73 (Allamufina), N 4, [K], Alm 25 < v.v. almûse, Pr.v.

\footnotetext{
${ }^{3}$ LKŽe neteisingai pateikiamas 648 puslapis.
} 
Almoßen 't. p.' (Q 22), n.v.a. Almosen 'išmalda'; plg. v.v.a. almuosen, s.v.a. alamuosan, s.s. alamosna, n.nl. almoes; vok. iš bažn. lot. elēmosyna f., o šis iš gr. eleēmosýne f. 'gailestis, užuojauta', vèliau ir 'išmalda' (Lexer I 40; Kluge 2002: 33); 1. elemozina. Plg. dar almūzas.

almũ̃zas sm. 'išmalda, dovana' C I 73 (orig. Almufai), N 4, [K], Alm $25<$ Pr.v. almus n. 't. p.' (Alm (PrW)), v.v. almûse (Lexer I 40); plg. n.nl. almoes, n.šv. allmosa, s.skand. olmusa (Kluge 2002: 33). Plg. dar almusina.

býbelès sf. pl. (1) 'Biblija, Šventasis Raštas' KlvD 364, K, Alm 31; býbelis sm. (1) LLICh 158 (orig. gen. sing. Bibelio), N 329 (Rg), NmŽ < Pr.v. bībal 'Šventasis Raštas' (Ziesemer I 593); plg. v.v.a. bībel f. 'knyga, Biblija', n.v.a. Bibel, bažn.lot. biblia ‘šventos knygos' (Lexer I 263; Kluge 2002: 119).

bybeliškas adj. 'būdingas Biblijai' N 329, K, Alm 31, adv. býbeliškai $\mathrm{K} \rightarrow$ bybelis; plg. n.v.a. biblisch.

býbelšprukis sm. 'Šventojo Rašto žodis' K I 238, Alm $31<$ n.v.a. Bibelspruch m. 't. p.'.

býbelštundè sf. 'laikas, skirtas Biblijos skaitymui' NmŽ < n.v.a. Bibelstunde f. 't. p.'.

decmonas sm. 'bažnytpinigiai, dešimtinè' B 341, Prel 54 (dẽcmonas), Alm 43; plg. Pr.v. Decem 'dešimtinè, mokestis dvasininkui' (Fr I 135), n.v.a. Kirchendezem 't. p.'; v.lot. decimanus 'exactor decimarum' (Prellwitz 1891: 54). Plg. dar tecmonas.

fir̂mmeliuoti verb. 'šventinti, konfirmuoti' K I 439, Alm 50 < n.v.a. firmeln 't. p.'; plg. lot. (con)firmāre 'sustiprinti' (Kluge 2002: 295).

gnóda sf. (1) 'malonė' N 266, K, Alm 55 < Pr.v. gnọd 't. p.' (Alm (PrW)); plg. n.v.a. Gnade f. 'malonè, gailestingumas', v.v.a. ge-nâde, gnâde 'ramybè; laimé, palaima; Dievo pagalba ir gailestis' (Lexer I 850).

katgismas sm. 'katekizmas, trumpas krikščioniu tikybos išdėstymas klausymų ir atsakymų forma' C I 222, 425 (orig. Katgífmas), B 85, 178, 300, R II 91, MŽ 119, K. Donel (katgizmas), katagismas Q 110, kategismas C I 425, katgìsmos pl. Lex 21, K I 679, K, Prel 61, Alm 64; katìsmos sf. pl. Prel 61 (katismos), Alm 64 < Pr.v. katxisem, katism, katismen, pl. Katissem (Fr I 345; Alm $(\mathrm{PrW})$ ); plg. n.v.a. Katechismus 'katekizmas' iš lot. catēchismus 'pamokymas tikèjime', iš gr. katēchēsis 'pamokymas'.

kèrũ்bas (kerubas) sm. (2) 'cherubinas, aukščiausiojo rango angelas' C I 428 (orig. Kerubas), B 311 (kerub’s), R II 91 (Kẽrubas), MŽ II 120 (Kẽrubas), N 197 (Kerubas), K (kèrũbas), Alm 65 (kèrũbas) < Pr.v. Cherub (C I 426), n.v.a. Cherub bažn. 'cherubinas'; plg. hebr. kerub (pl. kerubim) 't. p.'; [v.1.] n.1. cherub 'aukščiausiojo lygmens angelas ir kt.' iš lot. Cherub, pl. Cherūbim, Cherubin 'Se-

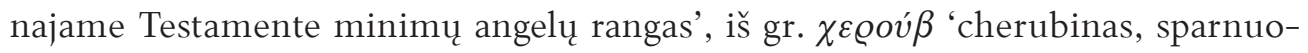
ta būtybè, sklandanti virš skrynios, kurioje saugomos 10-ties Dievo įsakymų 
akmens plokštès, duotos Mozei; angelas, vadeliojantis Dievo dangiškąji vežimaitį', iš s.hebr. pl. kərūbīm (LKPŽ 708).

kirkrots sm. 'bažnyčios taryba, kolegija' K I 687, kirkróts Alm 67 < n.v.a. Kirchenrat m. 't. p.' dialektizmo.

klebonpenigai (hibr.) sm. pl. bažn. 'dešimtoji pelno ar pajamų dalis, kurią tikintieji turẻdavo duoti bažnyčiai, klebonui; dešimtinè' Lex 23, Q 119; klebónpiningai C I 453 (orig. Lutter-Klebón-Patóbel-Pinningai), B 34; dūriniai iš sl. klebonas ir germ. penigai, piningai.

liuterè sf. 'liuteronų bažnyčiai tikinčiųjų mokama dešimtine’' B 794 (orig. pl. Lutteres), N 376 (Tlž, Lùttere); liùteris sm. N 376 (Rg, orig. Lùtteris), liùteriai pl. (1) K, Prel 55, Alm 82; $\rightarrow$ liuterpiningai 'dešimtinè, bažnytpinigiai, mokami liuteronų bažnyčiose'; plg. n.v.a. Luther 'Liuteris (asmenvardis)'.

Luter-Klebon-Patobel penigai (Luter [penigai], Klebon [penigai]) sm. pl. 'dešimtinè, bažnytpinigiai, mokami liuteronų bažnyčiose' Lex 23; dūriniai iš germ. liuteris ir penigai; iš sl. klebonas ir germ. penigai; iš germ. patobelis ir penigai.

põdženklis (hibr.) sm. (1) 'krikšto tẻvų puošnūs užantspauduoti lapeliai su linkèjimais, ị kuriuos įdedama dovana ar pinigai krikštavaikiui’ K II 105 (orig. põd-ženklis); dūrinys iš germ. podis ir liet. ženklas; plg. n.v.a. Patenbrief, Patenzettel 't. p.' (Grimm XIII 1502).

psalteras sm. Lex 69, C II 245, Q 398, H (orig. Pfalteras), N 317, Alm 106, KŽ 1. 'psalmès, psalmynas' BB Ps tit. 1. 2. 'styginis muzikos instrumentas' BB 1 Kar 10,12, BB 2 Sam 6,5, BB 1 Krn 14,8, BB Ps 71,22, BB Dan 3,5, BB Iz 5,12, BB Am 5,23, BB Ezd 12,27, BB 1 Sam 10 (Pfaltieras), RB 71,22, B 987, 'smuikas' R II 283, MŽ II 378; psaltérius (2) K, K II 116, KŽ; psalterius H 108, N 317 (Psalterus) 1. 'psalmynas' Mž 481 (gen. sing. ifch Psalteraus), 495 (ifch Psalteraus), psaltiẽrius (2) NdŽ. 2. 'styginis muzikos instrumentas' BB Ps 33,2 (ant Pfalteriaus), BB Ps 57,9, BB Am 6,5, RB Ps 33,2; 57,9, 'smuikas' R II 283, MŽ II 378; < Pr.v. Psalter 'Psalter' (Q 398; C II 245), v.v.a. psalter m. 'psalmiu knyga', n.v.a. Psalter m. 'psalmių knyga; citra, viduramžių muzikos instrumentas'; vok. iš bažn. lot. psaltêrium n. 'i citrą panašus styginis instrumentas; prk. Dovydo psalmès', o šis iš gr. psaltérion n. 'styginis instrumentas'; plg. n.nl. psalter (Lexer II 304; Kluge 2002, 727); 1. psatterz.

predikauti, -auja, -avo intr. 'sakyti pamokslą, viešai išbarti' C I 221, B 985, N 314, [K], Alm 104, KŽ, (spredekóti KŽ, spredikáuti Alm $118 \rightarrow$ spredika) < Pr.v. predigen 'daug kalbèti' (Alm (PrW)), v.v.a. bredigen, predigen, n.v.a. predigen 'sakyti pamokslą; prk. skelbti, propaguoti'; vok. iš lot. prædicare 'viešai skelbti'; plg. n.nl. prediken (Lexer I 345); v.v.ž. prediken 't. p.' (Sehwers 1953: 95), predeken 'sakyti pamokslą' (MndW III 372).

sprédika sf. (1) 'kalba, pamokslas' BzF 175 (TP 1881, 22), KŽ, Prk, spredika Alm 118, FrnW, spredeka KŽ, sprédikis sm. (1) 'kalba, pamokslas' TŽ II 
186 (Jnšk), LC 1880,27, sprìdikis sm. (1) NdŽ, APh VI 200, FrnW, Lnkv, Ms, Mžk, NmŽ, spredikas sm. Alm 118 < v.v.ž. predike 'pamokslas'; plg. pietų vok. Predig, v.v.a. bredige, predige f., s.v.a. prediga, n.v.a. Predigt f. 'bažn. pamokslas; prk. pamokymas'; vok. iš v.lot. predica 'viešas pranešimas, pamokslas' (Kluge 2002: 719; Lexer I 345); la. spredikis 'pamokslas' iš vok. (Sehwers 1953: 117).

šprùkknygès (hibr.) sf. pl. (1) 'pamokymų, sentencijų rinkinys, katekizmas' K II 199, NmŽ, šprùknygès 'maldų knygos' NmŽ; dūrinys iš germ. šprukas ir sl. knygos pl., plg. n.v.a. Spruchbuch n. 't. p.'.

tẽcmonas sm. (1) 'bažnytpinigiai, dešimtinè' N 93 (Lbgv), [K], Prel 54, Alm 141, KŽ; plg. Pr.v. Decem 'dešimtinè, mokestis dvasininkui' (Fr I 135), tętsen, tatsen 't. p.' (Alm (PrW)); lot. decem 'dešimt'. Plg. dar decmonas.

6) asmenų pavadinimai, pvz::

áptas sm. 'vyrų katalikų vienuolyno viršininkas' Lex 3a, Q 13 (orig. apts), [K 19], aptas Alm 27; abtas Alm 23 < Pr.v. Abt (Lex 3a), n.v.a. Abt m. 'abatas, vienuolyno viršininkas'; plg. v.v.a. abbet, abt, apt, s.v.a. abbat, v.nl. apt, abt, n.nl. $a b t$; vok. iš bažn. lot. $a b b \bar{a} s<$ gr. $a b b a ̃$ iš aram. $a b b \bar{a}$ 'tèvas' (Kluge 2002: 11; Lexer I 1); v.v.ž. abbet, abt (MndW I 1).

áptienè sf. 'katalikų vienuolyno viršininkè' Q 13, B 39 (orig. aptene), K I 33, aptiene Alm 27, abtienè sf. N 2 (abtẽne), Alm 23; vedinys iš germ. aptas, abtas.

bapstas sm. 'popiežius' [K], Alm 29, babstas N 317 < n.v.a. Bapst m. 't. p.', plg. v.v.a. bābst, bapst, s.v.a. bābes, n.v.a. Papst; vok. pasiskolino iš vèlyv. lot. pāpes (taip pat s.pranc. papes); $b$ vietoje $p$ dažnas ankstyvuose vok. skoliniuose (Grimm XIII 1448; Kluge 2002: 679; Lexer I 107).

býbelnešis (hibr.) sm. (1) 'Biblijos platintojas, išnešinètojas' LC 1882, 48; dūrinys iš germ. bybelè, bybelis ir liet. nešti.

bédelis sm. (1) 'velnias' Trg, Pgr, Erž; bíedelis Grk, Skr, Krš, Rs, Trg < v.v.ž. böd(d)el, v.ž. bödel 'teismo tarnautojas, budelis'; plg. n.v.a. Büttel, šv. bödel, s.pranc. bedel, s.s. budil (Kluge 1957: 115), v.v.ž. bêdel 'elgetavimas, prašinèjimas' (Alm 31), bedeler 'elgeta' (MndW I 169).

dómpropstas sm. 'katedros vyresnysis kunigas' K I 302 < n.v.a. Dompropst 't. p.'.

franciskõnas sm. 'elgetaujančių katalikų vienuolių ordino narys' K I 461, franciskonas Alm 51; plg. vok. Franziskaner 't. p.', 1. franciszkani pl. (Brückner 1974: 127).

iškunigis sm. (1) 'buvęs kunigas; ekskunigas' NdŽ, LzP; darinys iš germ. kunigas ir liet. praefikso -iš.

kañteris sm. (1) 'tam tikras protestantų bažnyčios pareigūnas, vargonininkas' Lex 21, C I 421, B 307, Q 108, N 178, K, Alm 62 < Pr.v. kanter 't. p.' (Riemann III 76; Alm (PrW), Canter (Lex 21), plg. n.v.a. Kanter; Kantor m. 
'kantorius, bažnytinio choro dirigentas; giedotojas'; n.nl. cantor; vok. iš lot. cantor 'giedotojas' (Kluge 2002: 487).

kapucýneris sm. 'katalikų vienuolių ordino, pranciškonų šakos narys; pavadinta dèl jų labai smailių kepurių, gobtuvų' Alm 63, kaputsýneris, kapcýneris K I 677 < n.v.a. Kapuziner m. bažn. 'kapucinas'; plg. it. cappuccini, lot. capucinus 'vienuolis kapucinas, pranciškonų vienuolis'.

katilikas, -è smob. (2) 'katalikas, kas išpažįsta katalikybę’ R I 56, R II 91, MŽ I 110, MŽ II 119, LLICh (Žodynèlis), K, Prel 26, Alm 64 < Pr.v. katelik 't. p.' (Alm (PrW)); plg. n.v.a. Katholik m. 'katalikas'; 1. katolik, lot. Christianus catholicus, pl. catholici.

kèceris sm. 'eretikas, atskalūnas' Alm 64, kètseris $\mathrm{K} \mathrm{I} 683$ < n.v.a. Ketzer m. 't. p.'; plg. v.v.a. ketzer, kätzer, kötzer 'kuris yra neteisingo tikejjimo'; pagal katarų (gr. katharós 'švarus, doras, skaistus, nekaltas') manichèjų sektą, v.lot. Cathari; vok. iš v.lot. catarus, gr.-lot. catharus (Kluge 2002: 485; Lexer I 1563).

kirkeversteris sm. 'bažnyčios viršininkas' Alm 66, kirkeverštèris K I 687 < n.v.a. Kirchenvorsteher m. 't. p.' dialektizmo.

kirkpoderis sm. 'bažnyčios tarnas, vargonininkas, zakristijonas' B 795; kirpoderis Q 297 (orig. Kirr=Poderis); kìrkevoderis sm. 'bažnyčios tarnas' K I 687, kirkevoderis Alm 66 < Pr.v.ž. Körchevader $(a=a ̊)$ 'bažnyčios viršininkas, bažnyčios kolegijos arba parapijos tarybos narys' (Fr I 363-364); plg. n.v.a. Kirchenvater.

kleknèrienè sf. 'varpininko žmona' K I 555, KŽ $\rightarrow$ klekneris.

klekneris sm. (1) ‘varpininkas' B 591, R II 180, 223, MŽ II 238, 298, Prk, klèkneris Sch 188-189, Prk; kleknorius B 831 (Kleknorus); klêknèrè sm. (1) 'varpininkas' K, K I 83, Prel 61, KŽ, klêkneré Alm 67 < Ryt. Pr.v. kleknə̌̌, klękner 'varpininkas' (Mitzka 1919: 124, Alm (PrW)); plg. v.v.a. glockenære 'varpininkas' (Lexer I 1037), n.v.a. Glöckner 't. p.', s.air. cloc(c) 'varpelis', n.nl. klok, n.šv. klocka (Kluge 2002: 362).

kocerus sm. 'atskalūnas, eretikas' $\mathrm{K}^{1} \mathrm{M}^{1} 13$, Lex 53a (orig. kocer[us]), C I 1054 (Kócerus), Q 295, B 434, 779, N 203; kocerius Mž 338 (acc. pl. Kocerius), DP 535 (kacerius), [K kocèrius], KŽ (kocèrius); kõcierius sm. (1) bažn. 'klaidatikis, atskalūnas, eretikas' DP 119, 541 (kacierius), MŽ II 296 (Kócierus), PG, K I 683 < v.v. katzer m. 'kuris yra neteisingo tikejjimo, eretikas' dialektizmo su $o$, nes Prūsijos ordino kalboje vietoje v.v.a. ilgojo atviro $\hat{a}$ dažnai buvo ilgasis atviras $\hat{o}$; vok. iš v.lot. catarus, gr.-lot. catharus (Lexer I 1563; Ziesemer 1924: 114); plg. Pr.v. Ketzer (C I 1054), v.v.a. ketzer (nuo XIII a.), kätzer, kötzer, n.v.a. Ketzer (Lexer I 1563; Kluge 2002: 485); (s.1., v.1.) n.l. kacerz 'eretikas, atskalūnas; eržilas'< s.ček. kacieř, n.ček. kacíř, kacér 'eretikas', iš v.v. [N.Č. - v.v. taisyta iš v.v.ž., nes v.v.ž. yra ketter] katzer, v.v.a. ketzer, n.v.a. Ketzer 't. p.', iš v.lot. catharus naujų sektų narių įvardijimas; neomanichèjininkų sektos narys' < gr. (LKPŽ 338-339), 1. kacerz iš ček. kacierz < vok. Katzer, Ketzer (Brückner 1974: 211). 
kunegbuvis (hibr.) sm. 'buvęs kunigas ar klierikas' Pron, Užv, kunigbuvis BŽ 477; dūriniai iš germ. kunegas, kunigas ir liet. būti.

kungas sm. 1. 'dvasininkas (ppr. katalikų)' $\mathrm{DK}^{1}$ 30, DK ${ }^{1}$ 32, AK 9,17, AK 66,19 (orig. pl. Kungay), KŽ. 2. 'ponas, viešpats' S. Dauk; plg. v.v. kunic, kunig, kong 'karalius; valdovas', s.v.a. chunig (Lexer I 1774), n.šiaur.germ. kung, n.šv. kung (Kluge 1957: 391; 2002: 520); la. kungs 'ponas' iš s.v.a. kunig (Sehwers 1953: 61). Plg. dar kunigas.

kunigáikštis (1) 'vyresnysis, vadovas, valdovas, kunigas, šventikas' BB $1 \mathrm{Moz} 23,6$, BB 1 Moz 36,15, VlnE 22,2 (orig. Kunigaigfchtis), VlnE 69,21 (Kunigaikfchtis), DP 3,6, DP 163, DP 167,44 (acc. pl. kunigáigszczius), DP 217,17, 467, 571, SD ${ }^{1} 67, \mathrm{SD}^{3}$ 27, 137, SP I 47, B 500, S. Dauk (kunegaikštis), R II 389, MŽ II $523 \rightarrow$ kunigas.

kunigáitis sm. (1) 'jaunas kunigas, vikaras; klierikas’ Šts, Mrc; vedinys iš kunigas.

kùnigas sm. $\left(3^{\text {b }}\right)$, FrnW, (kunegas) 'ponas, viešpats; vadas' Mž 396 (orig. Kunigs), 505, C I 908, B 53, 107, 681, 500, 511, 682, KlG 24, R I 70 (Kunnigs), MŽ I 135 (Kunig's), K, A 1884, 307, 308, A 1885, 37, K. Būg, rš, KŽ, kùnegas S. Dauk, dem. kunigelis B 379, kunigèlis B 499. 2. 'dvasininkas (ppr. katalikų, protestantų)' Mž 30, 127, 505, BP I 153, BP II 210, 278, DP 17,27; 75,44; 141,13, MT (Blotno prakalba) 7, MT 38,12, MP 40, 78, VP 26 (kunegas), $\mathrm{Ch}^{1} \mathrm{Mr}$ 1,44, AK 97, PK 160, Vln ${ }^{1} 150$, Vln 50,12, Vln 58,9 (Kunigs), VlnE 7,4, VlnE 51,20 (wiraufefiskunigas), VlnE 199,1 (pl. kunigai), ZEE 204,2 (pl. kunigai), RB tit. 1. 4, 12, SD 36, 116, SD 84, Lex 67, 68a, SP 69, SG I 35, Q 275 (Dwaronu Kunnigs), 383, 396 (Kunnigs), H 54, B 85, 210 (kunig's), 311, 313, 441, 543, 681, 721, 860, 873, 971, PVG 60 (1712 m.), PVG 93 (1728 m.), PVG 604 (1831 m.), R I 70, MŽ I 135, LLICh 216 (pl. Kunnigai), 255, K, M. Valanč, VP 26 (kunegas), K. Donel, S. Dauk, Rp 69, BzBk 110 (kunegas), Prel 44, NG 42, Drg 52, J, JV 1038, FrnW, Alm 75, Sim, GK 1939, 103, NžR, KŽ, ŠVŽŽ (gen. sing. kọnega, Šark, Šakal, Vin, Dauk, kọnẹs Lu), ZŠŽ (Grš, Br, Šk), KzRŽ, ZtŽ, DvŽ, LzŽ, Mrj, Šk, Srj, Ram, Vrnv, Gmb, Klp (kùnigs), Krš (kùnegas), Akm (kọnnegas), šiaurès panevėžiškiai (kú.nọgs), Dv, Plv, Ss, Šll, Pn, Pln, Zp, Klt, dem. kunigẽ lis KŽ, DvŽ, kunigẽlis KzRŽ; skolinys iš v.v. kunig 'karalius, valdovas'; plg. v.v.a. künic (Lexer I 1774); s.v.a. kuni(n)g, v.v.ž. kunig, kuning 'karalius, valdovas, viešpats', s.s. kuning (vèliau kunig), n.nl. koning, n.v.a. König 'karalius, valdovas'; suom. kuningas, est. kunningas (Kluge 1957: 391; 2002: 519-520; Grimm XI 1691); v.v.ž. konink, konnink 'karalius' (MndW II 524); pr. konagis 'kunigaikštis, karalius' taip pat germanizmas (Mažiulis II 242-243 (E 405)). Plg. dar kungas, kuningas, iškunigis, naujakunigis, pakunigis, puskunigis, senkunigis, velniakunigis, vištkunigis. 
kùnigè sf. (1) 1. 'moteris dvasininkè, vaidilutè' $\mathrm{S}$. Dauk, Pt, kùningé rš, 'vienuolyno, šventyklos vyresnioji, viršininke’’ SD³ 138, N 210, A 1884, 63, KŽ. 2. 'kunigo (pastoriaus) žmona' [K (Kt)], KŽ, I. Simon; $\rightarrow$ kunigas, kuningas. Plg. dar kuningé.

kunigẽlis sm. (2) 'vikaras’ NG 60, Sln, Skp, kunigẽlis ŠVŽŽ (Šts); vedinys iš kunigas.

kunigíenè sf. (1) Brž, kùnigiene (1) K; OsG 18 'kunigo (pastoriaus) pati’ R I 71 (orig. Kunnigẽnê), K, LC 1881, 17, Alm 76, KŽ $\rightarrow$ kunigas.

kunigijà sf. (2) col. 'kunigai, jų visuma' $M$, J, sp, FrnW, V. Kudir, KŽ, Prn, Bs, Blv, kunigija Alm 75, kuningijà A 1884, 381, kuningìja KŽ, Gmž; vediniai iš kunigas, kuningas.

kunigìnas sm. (2) 'pastorius' Prk; vedinys iš kunigas.

kùnigininkas, -è smob. (1) 'kunigo mokinys, rengiamas izžegnojimui' A 1885, 372, BsV 164, KŽ (orig. kuniginiñkas), Klp, Prk $\rightarrow$ kunigas.

kunigìnis, -è smob. (2) 'kas kunigo pažiūrų, kunigų šalininkas' rš, Žem, ZŠŽ (Grš); vedinys iš kunigas.

kùnigiškas sm. (1) 'kunigas' Slv; vedinys iš kunigas.

kunigišksis, -è smob. (2) 1. 'dvasininkas (ppr. katalikų)' Ch $2 \mathrm{Moz}$ 30,30, Grv. 2. 'kunigo mokinys, rengiamas įžegnojimui' KŽ, Šlu, Prk, kuningiškis N 210, K, KŽ; vediniai iš kunigas, kuningas.

kunigiùkas $\mathrm{sm}$. (2) 'klierikas' Jrb; dem. vedinys iš kunigas.

kunigùžis sm. (2) 'protestantų ar liuteronų kunigas' Alm 76, KŽ, ZŠŽ (Lkč, Žvr, Šk, Nm), Vdžg, Alk, Dkš, Gs, 'liuteronų kunigas' KrtnŽ; vedinys iš kunigas.

kùningas sm. $\left(3^{\text {b }}\right) \mathrm{FrnW}$ 1. 'ponas, viešpats; vadas' B 99, N 210. 2. 'dvasininkas (ppr. katalikų), klebonas’ C II 204 (orig. Kúnnigas), 237 (Kúnningas), 647 (Kunnings), 1121, Q 75 (Kunnings), 179, R I 70 (Kunnigs), R II 58, 208 (Kunningas), 276, 282, H II 186, PVG 193 (1748 m.), 362 (1793 m.), MŽ II 23, 78, 277, JV 615, Sln, BzF 52, N 210, K, KŽ (A 1883, 42), Prel 44, Šlv, dem. kuningèlis N 210, kuningytis N 210, kuningužis N 210; < v.v. kuninc, kuning 'karalius, valdovas' (Lexer I 1774); plg. s.v.a. kuni(n)g, v.v.ž. kunig 'karalius, valdovas, viešpats', s.s. kuning, n.nl. koning; suom. kuningas (Kluge 1957: 391; 2002: 519-520), v.v.ž. konink, konnink 'karalius' (MndW II 524); pr. konagis 'kunigaikštis, karalius' iš v.v.a. (ar v.v.) künic 'karalius', v.v. kunic (kunig) 'karalius' (Mažiulis II 242-243 (E 405)). Plg. dar kunigas.

kùningè sf. (1) 1. 'moteris dvasininkè, vaidilutè' rš. 2. 'katalikų vienuolyno vyriausioji, viršininkè' N 210, KŽ; $\rightarrow$ kuningas. Plg. dar kunigé.

kuningíenè R I 71 (orig. Kunnigẽnẽ), N $210 \rightarrow$ kuningas.

kuningystis sm. 'kardinolas, katalikų dvasininkas' Q 109 (orig. Kunningystis, Popezaus Kraffes) $\rightarrow$ kuningas. 
manìstas sm. 'menonitas, priklausantis protestantų sektai' $\mathrm{K}$ II 54, Alm 84, KŽ < Pr.v. Manist 't. p.'. Menonitai gyveno Prūsijoje, daugiausia Verderyje (Werder), Žemumoje (Niederungen) (Fr II 48); plg. v.v.ž. menniste 't. p.' (MndW III 71), n.v.a. Mennonist, pagal pastoriu Menno Simons (1496-1561, Nyderlandai).

mukaraĩ sm. pl. (3 $3^{\text {b }) ~ ' s e n i e j i ~ v o k i e c ̌ i a i, ~ k u r i e ~ p a p r a s t a i ~ m e l d z ̌ i a s i ~ n a m i e ’ ~ Z S ̌ Z ̌ ~}$ (Lkš), mùchariai sm. pl. (1) ZŠŽ (Ssr); mukeris ‘šventeiva' I.Simon, mùkuris (1) 't. p.' prš, $\mathrm{Y} 1<$ n.v.a. Mucker m. 'veidmainis, šventeiva, J. F. Budde pietistu pasekejjų XVIII a. pravardë'; plg. v.v.a. mûcheler m. 'Meuchler, sicarius' (Kluge 2002: 634-635; Lexer I 2191).

nacarènas, -è smob. 'nazarietis' Alm 90; plg. vok. Nazarener 'priklausantis judèjų krikščionių sektai (pirmaisiais mūsų eros amžiais)', lot. Nazareus iš gr. Nazarēnos 'Nazarietis, Jėzaus Kristaus prievardis'.

naujakunigis (hibr.) sm. 'neseniai î̌švęstas kunigas' Blv; dūrinys iš germ. kunigas ir liet. naujas.

pãkunigis sm. (1) 'protestantų kunigo padejejjas pasaulietis' Šts; darinys iš germ. kunigas ir liet. praef. $p a-$.

patóbelis sm. (1) 'bažnyčios tarnas, varpininkas, zakristijonas' Lex 43, Q 227, 297, C I 785, 1063, B 308, 591, 795, 831, R I 162, MŽ I 296, LLICh (Žodynèlis), N 107, [K], K I 555, KŽ, Alm 97, FrnW, Prk, 'bažnyčios patarnautojas, kuris stovèjo už lentos, vok. Tafel, kaip vertèjas' R I 162, MŽ I 296, Alm 97 < Pr.v. Potabel 'anksčiau [Prūsu] Lietuvoje bažnyčios tarnas, padedantis vokiečiu bažnyčios tarnams. Ju tarnyba - skambinti varpais, parūpinti vyno ir komunijos paplotėliu, tvarkyti bažnyčią ir jos įrankius, nešti maišeli aukoms rinkti (Klingsäckel), stebėti nestropius lankytojus, nepaklusniems uždèti geležinius antkaklius (Halseisen), patarnauti pamokslininkams, kai jie išvyksta pas ligonius ar ruošiasi krikštyti; jie taip pat turejjo būti renkant dešimtinę; ju pareiga - prižiūrèti pastatus ir padèti pamokslininkams žemès darbuose' (Fr II 172). ALEW rašoma, kad vok. Potabel (Patabel) galètų būti pasiskolintas iš liet. patóbelis (ALEW II 741-742).

piligrìmas, -è smob. (2) 'keliaujantis maldininkas, keliautojas į šventąsias vietas' TrpŽ, Š, DŽ pilgrìmas, $-\dot{e}$ brš, pilgrimas KŽ < Pr.v. Pilgrim, n.v.a. Pilgrim 'keliaujantis maldininkas' (Prel 40), s.v.a. piligrīm; plg. v.v.a. bilgerīm, pilgerīn, s.fryz. pilegrīm, v.ang. pilgrim; vok. iš v.lot. pelegrinus 'svetimšalis, keliautojas' (Kluge 2002: 703), v.v.ž. pelegrim(e) 't. p.' (MndW III 315); it. pellegrino iš lot.

põdè sf. (2) 'krikšto motina' C II 192, KŽ, Alm 103 (Aukštaitijoje), Pt, FrnW, ZŠŽ, KzRŽ, Šl, Jnš, Žml, Vl, Erž, Jrb, Sk; põde scom. (2) 'krikštavaikis’ N 294, K, M. Valanč, S. Dauk, BM 400 (Slnt), LMD (Šts), KŽ, Alm 103 (Žemaitijoje), NmŽ, FrnW, BM 400, Slnt, LMD (Šts), KrtnŽ (puodè), ŠVŽŽ (puode Bks, Meds, Lyk), Dr, Kv, Plt, Vkš, Sd, Trk, Ms, Nt, Trk, 'krikštaduktë' 
B 967 < Pr.v. pôde, pôt 'krikštatèvis, krikštavaikis' (Alm (PrW)); plg. v.v.ž. pade m. 'krikšto tèvas, krikšto motina, kūmas, kūma' (MndW III 291), n.v.a. Pate m. 'krikštatèvis; krikštasūnis'; f. 'krikštamotė; krikštaduktè', lot. pater 'dvasiškas tèvas, krikštatèvis' (Kluge 2002: 685).

precenteris $\mathrm{sm}$. 'parapinès protestantu bažnyčios vaikų mokytojas' PVG 413 (1794 m.) < Pr.v. prezenter 't. p.' (Alm 105 (PrW)); plg. lot. praecentor 'dainavedys, solistas, dirigentas'.

pùskunigis (hibr.) sm. (1) 1. 'liuteronų sakytojas, pamokslininkas, kunigo pareigas atliekantis žmogus' Grdm, Vn. 2. 'klierikas, turintis diakono šventimus' $\mathrm{NdŽ;} \mathrm{dūrinys} \mathrm{iš} \mathrm{germ.} \mathrm{kunigas} \mathrm{ir} \mathrm{liet.} \mathrm{pus-.}$

rabýneris sm. 'rabinas, judejų dvasininkas' K II 118, Alm 109 < n.v.a. Rabbiner 't. p.'; plg. hebr. rabbi 'mano mokytojas'; v.v.a. Râbînîs 'Araber' (Lexer II 330).

sénkunigis (hibr.) sm. (1) 'senas, senoviško mąstymo kunigas' Vaižg; dūrinys iš germ. kunigas ir liet. senas.

velniakunigis (hibr.) sm. 'kas blogais kèslais persirengęs į kunigus' BsV 291, S I 165; dūrinys iš germ. kunigas ir liet. velnias.

vištkunigis (hibr.) sm. pl. (1) 'kas nebaigęs kunigystès mokslų' $\mathrm{Nj}$, Skr; dūrinys iš germ. kunigas ir liet. višta.

7) mitologinè leksika, antgamtinių būtybių pavadinimai, pvz.:

baziliškas (basiliškas, baziliškus) sm. 'pasakų baidyklè, slibinas' WP 98a,8, SD 8, SD 9 (orig. bazylifžkas), Bb Iz 11,8, B 189 (Bafilifzkas), baziliškus Lex 236 (Bazilif3kus), C I 236, Prel 51 (bazylìszkas); plg. v.v.a. basiliske m., basilisk (Lexer I 133), n.v.a. Basilisk mit. 'baziliskas, slibinas', Pr.v. Bajilijzke (C I 236); n.nl. basilisk, n.ang. basilisk; vok. pasiskolintas iš lot. basiliscus, o šis iš gr. basilískos 'mažas karalius' (Kluge 2002: 94); 1. bazyliszek. ALEW liet. baziliškas kildinamas iš lenkų kalbos (ALEW I 100).

grãlis sm. 'paslaptingas ir stebuklingas indas (dubuo, taurè), akmuo (viduramžių vokiečių padavimuose, kūryboje)' TrpŽ, KŽ, NSŽ; 'legendinè taurè, iš kurios gèręs Jėzus Kristus per paskutinę vakarienę’ TrpŽ, NSŽ 144 < vok. Gral m. 'šventenybė (akmuo, taurè ar kt.)'; plg. v.v.a. grâl m. 'šv. gralis, Kristaus vakarienès dubuo', s.pranc. graal 't. p.', v.lot. gradalis (Kluge 2002: 367; Grimm VIII 1737; Lexer I 1066).

kãbalas sm. (1), ppr. pl. 'ateities spejjimas kortomis ir kitokiais būdais' Vad, Lp, Kt, kabõlai pl. ZtŽ; plg. Pr.v. kabâl 'nemalonumai' (Alm (PrW)), Cabale f. 'slaptos intrigos, pinklès' (K I 673), n.v.a. Kabale f. 'klasta, klastingumas; pinklès'; n.ang. cabal, n.šv. kabal, n.norv. kabale; vok. iš pranc. cabale 'kabala, judejjų, žydų slaptas mokslas', o šis iš hebr. qabbālā $(h)$ 'perdavimas; tradicija' (Kluge 2002: 457); hebr. gabbala '(slapta) tradicija', s.žyd. kabbālāh 'būrimas 
iš skaičių, magija, intriga' (Vasmer II 1986, 149); (v.1.), n.1. kabała, pl. kabaly 'judèju filosofinis apokrifinis traktatas; būrimas kortomis; būrimas iš ženklų, skaičių; burtų mokomoji knyga; sąmokslas, intriga; rūpesčiai, sunkumai'< 1 . jid. qabole 'paslaptingasis judèju mokymas', v.lot. cabbala 'Kabala (išmintis, perduodama rabinų)', iš v.hebr. qábbālāh 'gavimas, prièmimas; tradicijų perdavimas iš kartos i kartą; paprotinis ịstatymas; po Mozès rašyti veikalai; kabala, paslaptingoji išmintis'; n.brus. кабала́ 'rūpesčiai; galvosūkis; apgaulè, niekai', n.brus. dial. кабаль pl. 'būrimo kortos' (LKPŽ 337), 1. kabała 'intriga, slaptas mokslas' < vok. ir it. cabala, o šis iš hebr. kabbalah (Brückner 1974: 211).

špúkas sm. (1, 3) 'vaiduoklis, šmėkla, pamėklè' K II 200, Cp, NdŽ, BzF 185 (Prk), Alm 134, FrnW, KŽ, ZŠŽ (Grš, Šk, Ssr, Snt), NmŽ, Šn, Vlkv, Nm, Gs, Mrj, Tlž; špūkis, - $\dot{e}$ smob. 'kas nakti vaikščioja, naktibalda, vaiduoklis' J, BzF 185 (orig. szpúks); špókas (1) 'vaiduoklis, šmėkla’ ZŠŽ (Snt) < n.v.a. Spuk (Spuch) m. ‘šmèkla, vaiduoklis, pamèklè', kuris perimtas iš v.v.ž. spōk, spūk, n. 'vaiduoklis, šmėkla, niekinga būtybė'; plg. v.nl. spoke, s.ang. pūca mit. 'gnomas, barzdukas, kaukas, aitvaras, namų dvasia'. Kilmė neaiški (Kluge 2002: 871; MndW IV 335).

pracauberoti, -oja, -ojo verb. 'užburti, užkerèti' BzF $205<$ n.v.a. verzaubern 't. p.'.

Valhalà sf. 'senovès skandinavų mitologijoje - dievo Odino rūmai, mūšyje kritusių karių buveine’’ TrpŽ; dèl kilmès plg. vok. Walhall $(a)<$ s.skand. Valholl 'nužudytojų rūmai'; šiaurès germanų mitologijoje taip vadinama salè, vok. Halle, ị kurią ateina kritusieji kovose (Kluge 2002: 970).

valkìrijos sf. pl. (1) 'senovès skandinavų mitologijoje - karingos merginos deivès, kurios padėdavo karžygiams mūšiuose, nuvesdavo žuvusių karių vèles ị Valhalą ir ten per puotas jiems patarnaudavo' TrpŽ, NSŽ 454; plg. n.v.a. Walküre f. < s.skand. valkyrja 'pasirenkanti mirusius', n.šv. valkyria, n.ang. Valkyrie, n.nl. walkure (Kluge 2002: 970).

Valpùrgijos naktis 'senovès germanų pagoniška pavasario pradžios šventė naktị iš balandžio $30 \mathrm{~d}$. i gegužès $1 \mathrm{~d}$.; pagal vokiečių prietarus tą nakti ant Brokeno kalno piktosios dvasios ir raganos keldavusios puotą, orgijas; puota, orgija' TrpŽ, Valpurgija KŽ, NSŽ; plg. vok. Walpurgisnacht 'Hexensabbat'; Walpurg(is) yra germanų šventoji, kilusi iš Anglijos, vokiškai Walt-purc; gegužès 1-osios naktic joja raganos ant Blocksbergo kalno - ryšys tarp raganų ir šventosios yra motyvuotas tik data'; n.nl. Walpurgisnacht, n.ang. Walpurgis Night (Kluge 2002: 971); lot. Valpurgis. 


\section{DĖL ŽODŽIO OLA REIKŠMIŲ IR KILMĖS}

Bretkūno Biblijoje užfiksuotas žodis ola ${ }^{4}$ sf. 'urvas, landa, patalpa, kripta' (BB 1 Moz 23,9 'ola laidoti', BB 1 Kar 18,4, BB 1 Kar 19,9, BB 1 Kar 19,13, BB Ps 142,1, ole BB 1 Kar 18,4, ala BB 1 Sam 24,4, BB 1 Sam 24,11, uola BB 1 Sam 24,4). Olos, kaip paslaptingi vartai i požemini pasauli, yra daugelio kultų, mitų ir padavimų objektas. Jos buvo laikomos dievų gimimo vietomis, atsiskyrèlių buveinėmis. Kretos ir Mikènų tikèjime buvo daug šventų olų (NSŽ 294-296). Ola vartojamas ne tik reikšme 'žvèrelių ar paukščių urvas, landa', kaip pateikiama LKŽe, bet ir 'patalpa, kripta, vieta pasislèpti; prieglobstis'. Kriptos buvo ankstyvųjų krikščionių kulto ir laidojimo patalpos katakombose, požeminèse kapinèse. Iš Biblijos sužinome, kad olos buvo su durimis (1 Kar 19,13), didelès (paslépé oloje čia 50 ir ten 50 praraku (1 Kar 18,4)). Jose buvo laidojama - Antano Rubšio Šventojo Rašto (ŠvR, 1 Moz 23,19) vertime rašoma: Tada Abraomas palaidojo savo žmona Machpelos lauko oloje, priešais Mamrę \{tai yra Hebrona\}, Kanaano krašte. Laukas ir ola perëjo iš hetitu j Abraomo nuosavybę kaip kapaviete.

Bretkūnas ir jo išverstos Biblijos korektoriai turbūt abejojo, ar išverstų lietuvišku žodžių reikšmè tiksliai atitinka originalo žodị, todèl dažnai prirašomas ola, atitinkantis n.v.a. Höhle f. (Hohl n.), vidurio vokiečių Hohle f. 'ola, įduba; didelè tuščiavidurè patalpa žemejje’ (Grimm X 1714, 1715, PaulW 299); plg. vidurinès vokiečiu žemaičiuc tarmès hol n. 'ola, įduba, tuščiavidurè patalpa; prieglobstis, slèptuvè, XV a. Liubeko (Lübeck) miesto vienuolio dominikono Hermanno Kornero kronikoje, vokiečių žemaičių kalba parašytuose raštuose užfiksuotą verb. holen 'sich in eine Höhle, Versteck begeben (leistis, iškeliauti, eiti ị olą, slëptuvę)' (MndW II 285, 288). Lietuvių ola sietinas ir su v.v.a. hol n., m. 'ola, duobè, kiaurymé, įduba', v.v.a. hüle f. (hol) 'ola, prieglobstis, lindynè (Schlupfwinkel)', [hule BB 1 Moz 19,30], v.v.a. verb. hëln 'laikyti paslaptyje, paslèpti' (Lexer I 1324, 1381, 1242). Plg. dar giminišką s.skand. hǫll (n.v.a. Halle f. 'prieangis, priestatas iš kolonų'), kurio pagrindinè reikšmė yra 'uždengtas, paslëptas'; (gotų hallu-s 'uola, statinys iš akmenų, salè uolose'); $\rightarrow$ germ. *hel- 'slèpti, paslèpti'. Iš v.v.a. verb. hëlen, hëln 'laikyti paslaptyje, slèpti, paslèpti, slapstyti' (n.v.a. hehlen) kilo v.v.a. helle sf. mit. 'paslèptas, slaptas požeminis mirusiuju pasaulis, pragaras; siaura patalpa tarp krosnies ir sienos', v.v.a. halle f.

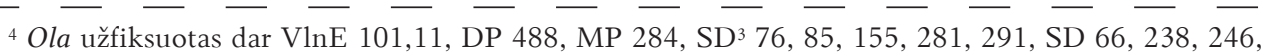
Q 235, B 860, R I 167 (orig. ůla), MŽ I 306 (ůla), A. Baran, J, JD 853, Jrk 25, FrnW, ZŠŽ (Grš, Šk, Br), KzRŽ, Ds, Dkš, Km, Sg, Skp, Rš, dem. olùké ZŠŽ (Lkš); turimi ir hola 'duobė, urvas' SP I 42,6; 42,11; 255,2, BzF 116, FrnW I 516, hala SD ${ }^{1}$ 44, BzF 116.

${ }^{5}$ Plg. dar s.v.a., v.nl., s.fryz. hol, ang. hole ‘ola, urvas' (Kluge 1957: 313). 
'medinis bokštas, medinès kolonos, trobelè; vieta ruošti ir saugoti druskai'; plg. dar got. halja 'požeminis mirusiųju pasaulis' (Lexer I 1232, 1149; Kluge 1957: 283; Grimm X 229). W. Smoczyńskis lietuvių ola laiko neaiškios kilmės žodžiu (Smoczyński 2007: 432). Latvių ala 'ola, urvas, landa' J. Sehwers kildina iš v.v.ž. hol 'ola, skylè, įduba' (Sehwers 1953: 1).

Taigi lietuviu ola 'urvas, dauba, patalpa, kripta; prieglobstis', užfiksuotas XVI a. Bretkūno Biblijoje, galètų būti kildinamas ne tik iš vidurinès vokiečiu žemaičių tarmès hol n. 'ola, urvas, tuščia patalpa; prieglobstis', kaip rašè E. Fraenkelis, bet ir iš vidurio vokiečių Hohle f. 'ola, įduba; didelè tuščiavidure patalpa žemėje'; plg. vidurinès vokiečiu aukštaičių tarmès hüle (hule, hol) f. 'urvas, duobė, prieglobstis'. Plg. dar Valhala (prie 2, 7).

Antano Rubšio verstame Šventajame Rašte randame skolini šeolas sm. 'mirusiujų buveinè, pragaras’ ŠvR (Moz 37,35; GG 8,6; Job 24,19), kilusị tikriausiai iš hebr. še'ol, kuris turbūt sietinas su n.v.a. Hölle f. 'požeminis mirusiųiu pasaulis, pragaras', got. halja, s.v.a. hella 'mirties deivè Hel, jos gyvenamoji vieta' (Grimm X 1747); plg. la. elle 'pragaras' iš v.v.ž. helle (Sehwers 1953: 331-332). Ankstesniuose senuosiuose lietuvių raštuose, turimais duomenimis, žodis šeolas neaptinkamas. XVI a. Bretkūno Biblijoje vok. Hölle f. 'pragaras' išverstas skoliniu iš lenkų kalbos peklà ${ }^{6}$.

\section{DARINIAI}

Iš religinès leksikos germanizmų sudaromi nauji žodžiai: vediniai, denominatyvai, dūriniai. Ypač dažnai prie germanizmo šaknies pridedamos lietuviškos priesagos -iene, -yste, -iškas, -auti. Turima ir sudurtinių žodžiu, hibridų, kurių vienas dėmuo yra germanizmas, o kitas - lietuviškas žodis. Daug darinių sudaryta su senuoju germanizmu kunigas.

Vediniai, pvz.: áptiené, abtiene sf. 'katalikų vienuolyno viršininkè' $\rightarrow$ aptas, abtas; kunigíene, kùnigienè, kuningíenè sf. (1) 'kunigo (pastoriaus) pati'. Ypač daug vedinų sudaryta iš skolinių kunigas, kuningas: kùnigé, kùningé sf. (1) 1. 'moteris dvasininkè, vaidilutè; vienuolyno, šventyklos vyresnioji, viršininkè'. 2. 'kunigo (pastoriaus) žmona'; $\rightarrow$ kunigas, kuningas; kunigáitis sm. (1) 'jaunas kunigas, vikaras; klierikas'; kunigystà sf. (2) 'viešpatystè' BP II 117, WP 27,13, DP 226, MT 30,31, 'kunigo pareigos, kunigavimas' WP 27,13, DP 465, MT 18, Alm 76, FrnW, KŽ, KrtnŽ; kunigỹstè sf. (2) 'viešpatystë’ BB Joz 18,7, WP 152,19, DP 542, SP 204, B 684, R I 71, MŽ I 136, PG, 'kunigo pareigos,

\footnotetext{
${ }^{6}$ LKŽe nepateikiamas žodžio peklà šaltinis iš Bretkūno Biblijos.
} 
kunigavimas’ BB 1 Sam 2,28, DK 94, AK 93, DP 75, MT 18, $\mathrm{Ch}^{1}$ 312, PK 13, SD $^{3}$ 96, SD 84, SG I 51, Lex 68a, Q 396, B 721, 810, 986, H 54, R I 71 (orig. Kunnigystè), MŽ I 136, A 1885, 35, K, M. Valanč, M, FrnW, J. Bil, J. Šimk, KŽ, ŠVŽŽ (Dauk), kuningỹstè (2) 'kunigo pareigos, kunigavimas' Lex 68a, C II 237, Q 396, H 54, R I 71 (Kunnigystè), R II 282, N 210, A 1885, 78, 'viešpatystè' R I 71, N 210; kecerỹstè sf. 'erezija; paklydimas (tikejjime)' Alm 64; bybeliškas adj. 'būdingas Biblijai' N 329, K, Alm 31, adv. býbeliškai K; $\rightarrow$ Bybelis; plg. n.v.a. biblisch; kètseriškas adj. 'būdingas keceriui' K I 683, adv. ketseriškai K I 683; kùnigiškas, - $a$ adj. (1), -à ( $\left.3^{4 b}\right)$ 'būdingas dvasininkui (ppr. katalikų)' BB 2 Moz 19,6, DK 147, DP 27, 76, 547, SD³ 96, SD 84, B 986, K, BsMt II 238, M. Valanč, J. Jabl, KŽ, Ggr; kùningiškas, -a R II 282, N 210, A 1885, 81, adv. kùnigiškai 'kaip kunigas' K, ZŠŽ (Nm); kunigìnis, - $\dot{e}$ adj. (2) 'dvasininkų (ppr. katalikų)' J. Jabl, KŽ, Šts.

Denominatyvai: kunigáuti, -áuja (-áuna), -ãvo intr., kunigáut ZŠŽ 1. 'būti kunigu, dvasininku’ Mž 421, BB Luk 1,8, S. Dauk, BzB 297, FrnW, P. Cvir, J. Jabl, J. Balt, Alm 75, KŽ, DŽ, ŠVŽŽ (Žbr). 2. 'viešpatauti' Mž 421, MT 250, rš; denominatyvas iš kunigas; podžiáuti, -iáuja, -iãvo intr. 'būti podžium ar pode, kūmauti' rš, ZŠŽ (Jnk), apipodžiáuti tr. 'pabūti podžiais, kūmais' ZŠŽ (Jnk), denominatyvas iš podžius; spredikauti verb. intr. 'sakyti pamokslą' Alm 118, spredekóti KŽ, denominatyvai iš spredika; pilgrinauti, -auja, -avo verb. intr. 'keliauti į šventąsias vietas' BB Iz 23,7, Prel $43 \rightarrow$ pilgrimas; plg. v.v.ž. pelegrine ‘piligrimas' (Prel 43).

Dūriniai: býbelnešis (hibr.) sm. (1) 'Biblijos platintojas, išnešinètojas' LC 1882, 48, dūrinys iš germ. bybelè, bybelis ir liet. nešti; iškunigis sm. 'buvęs kunigas, ekskunigas' NdŽ, LzP, darinys iš germ. kunigas ir liet. praef. -iš; kirrkapis (hibr.) sm. (1) 'kapai prie kirkès; šventorius' R I 54, R II 223, MŽ II 298, N 200, K, KŽ, Alm 66, kirkkapis KŽ, dūrinys iš germ. kirkè ir liet. kapas; plg. n.v.a. Kirchhof m. 'kapai, kapinès'; kunegbuvis (dial.) sm. 'buvęs kunigas ar klierikas' Pron, Užv; kunigbuvis BŽ 477, dūriniai iš germ. kunegas, kunigas ir liet. būti; Luter-Klebon-Patobel penigai (Luter [penigai], Klebon [penigai]) sm. pl. 'dešimtinè, bažnytpinigiai, mokami liuteronų bažnyčiose' Lex 23; dūriniai iš germ. liuteris ir penigai; iš sl. klebonas ir germ. penigai; iš germ. patobelis ir penigai; põdženklis (hibr.) sm. (1) 'krikšto tèvų puošnūs užantspauduoti lapeliai su linkèjimais, ị kuriuos įdedama dovana ar pinigai krikštavaikiui’ K II 105 (orig. põd-ženklis); dūrinys iš germ. podis ir liet. ženklas; plg. n.v.a. Patenbrief, Patenzettel 't. p.' (Grimm XIII 1502); šprùkknygès sf. pl. (1) 'pamokymų, sentencijų rinkinys, katekizmas' K II 199, NmŽ, šprùknygès 'maldų knygos' NmŽ, dūrinys iš germ. šprukas ir liet. knygos pl.; plg. n.v.a. Spruchbuch n. 't. p.'. 


\section{CHRONOLOGINÉS PASTABOS}

Nedaug religijos srities žodžių užfiksuota pirmuosiuose XVI a. senuosiuose raštuose, kiek daugiau jų rasta Bretkūno Biblijoje, pvz.: kunigas (kunegas, kungas); turmas 'bokštas, varpinè'; psalteras (psaltếrius, psaltieras) 'psalmynas; styginis muzikos instrumentas'; miras (mirras, myras) 'kvapūs sakai'; izopas (yzopas, yzapas) 'vaistinis juozapas (Hyssopus officinalis); yzopo šakelès bažnyčioje kaip šlakstyklè'; skryne 'katalikų bažnyčioje puošni spintelè altoriaus viduryje ostijai laikyti; aukų děžè, kasa; laivas (apie biblinio Nojaus įrengtą laivą)'.

Nuo XVII a. skolinių daugejja, ypač Prūsijos vokiečių-lietuvių ir lietuviųvokiečių žodynuose, pvz.: ablótas 'kalèdaitis'; almũuzas 'išmalda, dovana'; i ilgès sf. pl. (2), ìlgès (1) 'Visų Šventųių šventė (lapkričio 1 d.)'; kañteris 'tam tikras protestantų bažnyčios pareigūnas, vargonininkas'; katgismas 'katekizmas, trumpas krikščionių tikybos išdèstymas klausymų ir atsakymų forma'; kèrũ $\boldsymbol{b} a \boldsymbol{s}$ (kerubas) bažn. 'aukščiausiojo rango angelas'; plg. vok. Cherub, Pr.v. Cherub (C I 426), hebr. kerub (pl. kerubin) 't. p.'; asirų k' rub 'milžiniškas paukštis su liūto letenomis ir žmogaus galva, grifas' (Kluge 1957: 268); kirpoderis 'bažnyčios tarnas, vargonininkas, zakristijonas', kirkpoderis; klebonpenigai sm. pl. bažn. 'dešimtoji pelno ar pajamų dalis, kurią tikintieji turẻdavo duoti bažnyčiai, klebonui; dešimtinè'; dūrinys iš sl. klebonas ir germ. penigai; klebónpiningai (orig. Lutter-Klebón-Patóbel-Pinningai); gángos sf. pl. (1) 'bažnyčioje vieta prie vargonų; viškos'< vok. Gang 't. p.'; predikauti, -auja, -avo intr. 'sakyti pamokslą, viešai išbarti'; tapelis 'maišelis aukoms bažnyčioje rinkti' $<$ Pr.v. tofel 'plokšste', plg. Elzaso dial. tôfel '(pakabinta) plokštė, lenta, mušama išgauti garsui, duoti ženklą, naudojama bažnyčiose, vienuolynuose vietoje skambinimo', n.v.a. Tafel (Grimm XXI 13).

XVIII a. randama naujų skolinių, nemažai jų pateikiama Jokūbo Brodovskio žodyne, pvz.: dreskamara sf. 'zakristija', dréskamaré, dryskamaré LC 1885, 12; kapele 'maža bažnytėlè, koplytėlè'; klekneris 'varpininkas'; klingbidelis 'maišelis pinigams bažnyčioje rinkti'; klosteris 'vienuolynas'; precenteris 'parapinès protestantų bažnyčios vaikų mokytojas' PVG 413 (1794 m.); hibr. kirkapis 'kapai prie kirkès, šventorius'.

Nuo XIX a. užfiksuota naujų skolinių G. H. F Nesselmanno ir ypač F. Kuršaičio žodynuose, pvz.: bybelis sm., býbelès sf. pl. 'Biblija'; býbelšprukis 'Šventojo Rašto žodis'; verb. fir̃meliuoti 'šventinti, konfirmuoti'; franciskõnas 'elgetaujančių katalikų vienuoliu ordino narys'; gnóda 'malonë'; jergutãliau interj. 'Dievulèliau, Dievuli'; kapucýneris (kaputsýneris) 'katalikų vienuolių ordino, pranciškonų ordino šakos narys, pavadinta pagal ju ypač smailius gobtuvus'; liktìs sf. $(4,2)$ 'Grabnyčių šventė; pamaldos, ị kurias tikintieji eina su žvakèmis (vasario 2 d.)'; liturgìja 'viešųiu pamaldų, ypač mišių, tvarka krikščioniu 
bažnyčiose' < vok. Liturgie 't. p.', plg. n.nl. liturgie, bažn.lot. liturgia, gr. leitourgía (Kluge 2002: 578); própstas 'klebonas'; rabýneris 'rabinas'; sprédika sf. (1) 'kalba, pamokslas', spredika Alm 118, FrnW, spredeka KŽ, spredikas sm.; šprukknygès pl. 'pamokymų, sentencijų rinkinys, katekizmas'; tõbelis 'maišelis aukoms bažnyčioje rinkti'. A. Bezzenbergerio darbuose pirmiausia pateikti žodžiai: bèrès sf. pl. 'laidotuvių vaišès, šermenys' BzF 99; plg. Pr.v. Behre 'puota dailidèms' (Ziesemer I 530), v.v.ž. böre 'neštuvai’ (Sehwers 1953: 11), s.fryz. bere 'neštuvai', n.v.a. Bahre f., vèlesnè reikšmè 'neštuvai mirusiam nešti' (Kluge 2002: 83), v.v.ž. boringe f. 'pakèlimas, paėmimas; auka (Hebung, Einnahme)' (MndW I 397, VI 80); la. bēres 'neštuvai numirusiam nešti' iš v.v.ž. böre ar rytų fryzų bēre 'neštuvai' (Karulis I 121); pracauberoti 'užburti, užkerèti' BzF 205 (Dargùžiai), Prel 58 (pracauberots).

Daug šios teminès grupès skolinių užfiksuota Aleksandro Kuršaičio keturių tomų lietuvių-vokiečių žodyne, išleistame 1968-1973 m. (grãlis sm. 'paslaptingas ir stebuklingas indas (dubuo, taurè), akmuo (viduramžių vokiečiuc padavimuose, kūryboje); legendinè taurè, iš kurios gèręs Jèzus Kristus per paskutinę vakarienę'; ilgikristis sm. (2) 'Kūčios (?), pl. Kūčių dovanos'; dūrinys iš v.v.ž. hilgen 'šventieji' ir liet. Kristus, plg. vok. der heilige Christabend; kirvelis 'parapijinè šventė (minint bažnyčios pašventinimą); mugè (ryšium su parapijine švente)'; nacarènas, $-\dot{e}$ smob. 'nazarietis' Alm 90.

\section{IŠVADOS}

Prūsijos raštijoje, žodynuose užfiksuota nemažai religinès leksikos skolinių iš germanų kalbų, nes Mažąą Lietuvą krikštijo vokiečiai, jie ilgai valdè ši kraštą. Kadangi vienuolių ordinai dalyvavo tame procese, todèl lietuvių kalboje yra vokiečių kilmès vienuolynų ir vienuolių pavadinimų: aptìja 'katalikų vienuolynas', klosteris 'vienuolynas', kapucýneris 'katalikų vienuolių ordino, pranciškonų ordino narys, pavadinta pagal jų ypač smailius gobtuvus', franciskõnas 'elgetaujančių katalikų vienuolių ordino narys', kitų dvasininkų pavadinimų; pastatų; bažnyčios apeigų reikmenų; švenčių ir kitų pavadinimų.

Pagal kilmę religinė ir mitologinè skolintiné leksika yra: 1) skoliniai iš germanų kalbų, daugiausia vokiečių kalbos; 2) graikų (pvz., psalteras), lotynų (pvz., skrynè), hebrajų (pvz., kerrübas 'aukščiausiojo rango angelas' iš hebr. kerub (pl. kerubim), aramèjų (aptas 'vienuolyno viršininkas'), senosios prancūzų (pvz., gralis) ir kitų kalbų žodžiai, patekę ì lietuvių kalbą iš germanų kalbų.

Pirmieji germanų kilmès religinès leksikos žodžiai, užfiksuoti XVI-XVII a. lietuvių raštijoje, kilo daugiausia iš vidurio vokiečių, vidurinès vokiečių aukštaičių tarmès. Mitologinès leksikos yra nedaug, dauguma jos užrašyta tik XIX a. 
Kai kurie religinės leksikos skoliniai yra bendri lietuvių ir latvių kalbose. Jie turi atitikmenų kitose Europos kalbose.

Lietuvių žodžio olà reikšmė yra ne tik 'žvèrelių ar paukščių urvas, landa', kaip pateikiama LKŽe, bet XVI a. Bretkūno Biblijoje jis užrašytas ir reikšme 'patalpa (laidoti), kripta; prieglobstis', kuriuo išverstas vokiečiu kalbos Höhle f. (vidurio vokiečių dial. Hohle), Hohl n. Lietuvių žodis olà sietinas su v.v.ž. hol n. 'urvas, ola; prieglobstis', v.v.a. hüle (hule, hol) f. 'urvas, duobè, prieglobstis', n.v.a. Hohl n. 'urvas, guolis, įduba, įdubusi tuščia patalpa', germanų *hel- 'paslëpti', v.v.a. verb. hëlen, hëln 'laikyti paslaptyje, slëpti, paslèpti', v.v.ž. helen, s.v.a. helan, s.s. helan.

Dauguma religinès leksikos germanizmų pateikiama tik lietuvių senuosiuose raštuose, Prūsijoje leistuose žodynuose. Kai kurie religinès leksikos skoliniai vartojami paprastai tik gyvojoje kalboje, tarmèse, pvz.: bédelis 'velnias' Trg, Pgr, Erž (biedelis Grk, Skr, Krš, Rs, Trg); bybelštunde 'laikas, skirtas Biblijos skaitymui' NmŽ; hibr. jer̃gumano interj. 'Dieve mano' Šts, dūrinys iš germ. jergau ir liet. ịvardžio mano, plg. jergutalis; kañtaras 'giedotojas' ZŠŽ (Šakių apyl.), plg.

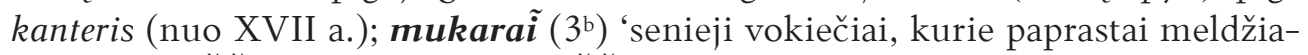
si namie' ZŠŽ (Lkš), muchariai ZŠŽ (Ssr), mùkuris prš, Yl, mùkeris 'šventeiva' Prk; podina $\tilde{i}$ sm. pl. (3 $\left.3^{\mathrm{b}}\right)$ 'krikšto tèvai, podis ir podè' Šl, Mšk, põdinai (1) Vkš, Žml, põdinas sm. (1, 3 ${ }^{\text {b }}$ ' 'krikštatèvis, podis' FrnW, Žg, Mšk, Šl, Jnš, Lg, Žml, Pš, Lnkv, Ps, dem. podinùkas, -i smob. (2) 'krikšto vaikas' Gs, ZŠŽ (Šakių apyl.), vedinys iš podinas; šprùkai pl. 'maldos' NmŽ. Plačiausiai gyvojoje kalboje paplitę žodžiai: kùnigas (kùnegas), põde 'krikšto motina; krikštavaikis', põdis 'krikšto tèvas, krikštamotè', põdžius 'krikšto tèvas, podis', põdžiai sm. pl. 'krikšto tèvai, podis ir podè', põdinas 'krikštatèvis', interj. jer̃gutalis 'Dievulèliau, Dievulèli', sprìdikis 'kalba, pamokslas', bédelis (biedelis) 'velnias'.

\section{SANTRUMPOS}

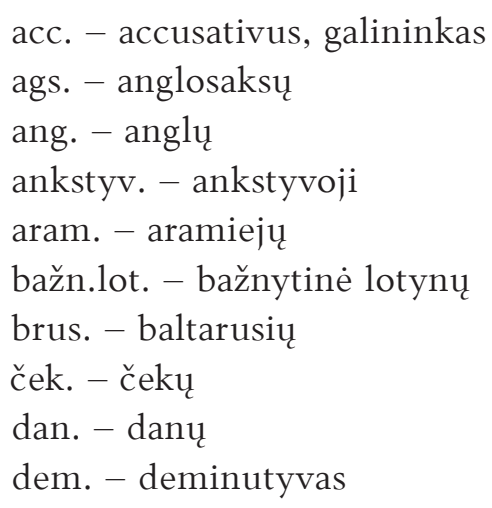

$$
\begin{aligned}
& \text { dial. - dialektas } \\
& \text { est. - estų } \\
& \text { fryz. - fryzų } \\
& \text { gen. - genitivus, kilmininkas } \\
& \text { germ. - germanuc } \\
& \text { got. - gotuc } \\
& \text { gr. - graikų } \\
& \text { hebr. - hebrajų } \\
& \text { hibr. - hibridas } \\
& \text { instr. - instrumentalis, įnagininkas }
\end{aligned}
$$




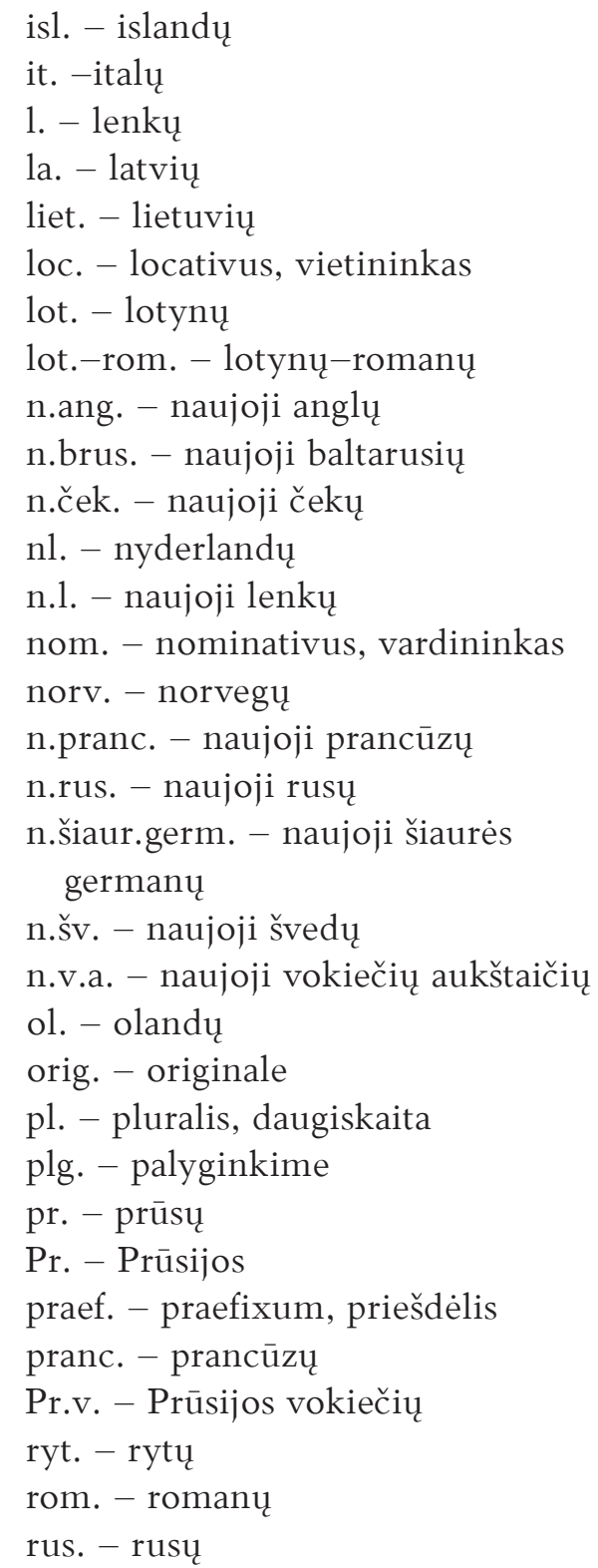

s.air. - senoji airiu

s.brus. - senoji baltarusiu

s.ček. - senoji čekų

s.fryz. - senoji fryzu

s.hebr. - senoji hebraju

sing. - singularis, vienaskaita

sk. - skirsnis

s.1. - senoji lenku

s.pranc. - senoji prancūzų

s.rus. - senoji rusų

s.s. - senoji saksuc

s.skand. - senoji skandinavu

suom. - suomiuc

s.v.a. - senoji vokiečių aukštaičių

s.žyd. - senoji žydų

šv. - švedų

tit. 1. - titulinis lapas

t. p. - taip pat

v.a. - vokiečių aukštaičių

v.ang. - vidurinè anglų

v.hebr. - vidurinè hebraju

v.l. - viduriné lenku

v.lot. - viduriné lotynu

v.nl. - vidurinè nyderlandu

vok. - vokiečiuc

v.ol. - vidurinė olandu

vulg. - vulgarizmas

v.v. - vidurio vokiečiu

v.v.a. - vidurinè vokiečiuc aukštaičiuc

v.v.ž. - vidurinè vokiečių žemaičiu

v.ž. - vokiečių žemaičių

žyd. - žydų

\section{LITERAT ŪRA IR ŠALTINIAI}

ALEW - Altlitauisches etymologisches Wörterbuch (ALEW). Unter der Leitung von Wolfgang Hock und der Mitarbeit von Elvira-Julia Bukevičiūte und Christiane Schiller, bearbeitet von Rainer Fecht, Anna Helene Feulner, Eugen Hill und Dagmar S. Wodtko. Band 1. A-M, Band 2. N-Ž, Band 3. Verzeichnisse und Indices. Hamburg: Baar Verlag, 2015. 
Alm - Die Germanismen des Litauischen. Teil 1: Die deutschen Lehnwörter im Litauischen von Dr. K. Alminauskis. Kaunas: Šv. Kazimiero d-jos knygynas, [1934]. Alm (PrW): W. Ziesemerio Preussisches Wörterbuch rankraštis, kuriuo pasinaudojo K. Alminauskis. B - Lexicon Germanico-Lithvanicvm et Lithvanico-Germanicvm, darinnen ... von Jacobo Brodowskij, Praecentore Trempensi. 1713-1744 m. rankraštis, du tomai. Msc. 127, 128. Jokūbas Brodovskis. Lexicon Germanico-Lithvanicvm et Lithvanico-Germanicvm. Rankraštinis XVIII amžiaus žodynas. Dokumentinis leidimas su faksimile, perrašu ir žodžių registru. Parengè Vincentas Drotvinas. 3 tomai. Vilnius: Lietuvių kalbos institutas, 2009.

BB - Biblia tatai esti Wissas Schwentas Raschtas Lietuwischkai pergulditas per Jana Bretkuna Lietuwos Plebona Karaliaucziuie (1590 m. rankraščio fotokopija).

Brückner Aleksander 1974: Słownik etymologiczny języka polskiego. Warszawa: Wiedza Powszechna.

C - Clavis Germanico-Lithvana. (Buv. Karaliaučiaus archyvo dviejų tomų (I AalLust: Msc 85 in 40; II Maal-Zwölfter: Msc 86 in 40) rankraštis, parašytas tarp 1673 ir 1701 metų.) Clavis Germanico-Lithvana. Rankraštinis XVII amžiaus vokiečių-lietuvių kalbų žodynas. Keturios dalys: I A-E, 1995; II F-L, 1997; III M-S, 1997; IV T-Z, (1997). Vilnius: Mokslo ir enciklopedijų leidybos institutas.

Čepienè Nijolè 2006: Lietuvių kalbos germanizmai ir jų fonetinès ypatybès. Vilnius: Lietuvių kalbos instituto leidykla.

DvŽ - Dieveniškiu šnektos žodynas. Vilnius: Lietuvių kalbos institutas. T. I: A-M, aut. L. Grumadienė, D. Mikulènienè, K. Morkūnas, A. Vidugiris, 2005; T. 2: N-Ž, aut. D. Mikulènienè, K. Morkūnas, A. Vidugiris, 2010.

Fr - Preussisches Wörterbuch. Ost-und Westpreussische Provinzialismen in alphabetischer Folge von H. Frischbier, 1-2. Berlin: Verlag von Th. Chr. Fr. Enslin, 1882.

FrnW - Litauisches etymologisches Wörterbuch von Ernst Fraenkel 1-2. Göttingen, 1955-1965.

Georges 2004: Lateinisch-Deutsch. Deutsch-Lateinisch. Ausführliches lateinischdeutsches Handwörterbuch, Kleines deutsch-lateinisches Handwörterbuch von Karl Ernst Georges. Faksimile und Volltext. Zweite, erweiterte Ausgabe. Directmedia. Berlin.

Grimm 2004: Der digitale Grimm. Deutsches Wörterbuch von Jacob und Wilhelm Gri$\mathrm{mm}$. Elektronische Ausgabe der Erstbearbeitung. Zweitausendeins.

$\mathrm{H}$ - Vocabvlarivm Litthvanico-Germanicvm et Germanico-Litthvanicvm. Darin alle im Neuen Testament und Psalter befindliche Wörter nach dem Alphabeth enthalten sind;... 
Ausgefertiget von Friederich Wilhelm Haack / S. S. Theol. Cultore, zur Zeit Docente im Litthauischen Seminario zu Halle. Halle [1730].

K - Littauisch-deutsches Wörterbuch von Friedrich Kurschat. Halle a. S., 1883. Deutschlittauisches Wörterbuch von Friedrich Kurschat. Halle, I - 1870, II - 1874. (Skaitmenys rodo dalis ir puslapius.)

Karulis Konstantins 1992: Latviešu etimologijas vārdnīca 1-2. Rīga: Avots.

Kluge Friedrich 1957, 2002: Etymologisches Wörterbuch der deutschen Sprache, 17 Auflage. Berlin: Walter de Gruyter \& Co, 1957; Etymologisches Wörterbuch der deutschen Sprache, 24 Auflage, Berlin / New York: Walter de Gruyter, 2002.

KrtnŽ - Juozas Aleksandravičius. Kretingos tarmès žodynas. Lietuvių kalbos institutas, 2011.

KzRŽ - Aldonas Pupkis. Kazlu Rūdos šnektos žodynas. 1. A-M, 2008; 2. N-Ž, 2009. Lietuvių kalbos institutas.

KŽ - Aleksandras Kuršaitis. Lietuviškai-vokiškas žodynas ... Göttingen. I - 1968, II 1970, III - 1972, IV - 1973.

Lasch Agathe 1914: Mittelniederdeutsche Grammatik. Halle a. S.: Verlag von Max Niemeyer.

Lex - Lexicon Lithuanicum. (Buv. Karaliaučiaus archyvo XVII a. rankraštis.) Msc. 1784. Lietuvos mokslų akademijos Vrublevskių biblioteka. Lexicon Lithuanicum. Rankraštinis XVII a. vokiečių-lietuvių kalbų žodynas. Parengè V. Drotvinas. Vilnius: Mokslas, 1987.

Lexer: Lexer - Wörterbuchnetz. Mittelhochdeutsches Handwörterbuch von Dr. Matthias Lexer. 3 Bde. Leipzig: Verlag von S. Hirzel, 1872-1878. Elektronische Ausgabe.

LKA I 1977 - Lietuvių kalbos atlasas. Leksika. Vilnius: Mokslas.

LKPŽ - Kregždys Rolandas. Lietuvių kalbos polonizmų žodynas. Vilnius: Lietuvių kalbos institutas, 2016.

LKŽ - Lietuvių kalbos žodynas 1-2. Vilnius: Mintis, 1968-1969; 3-6. Vilnius: Valstybinè politinès ir mokslinès literatūros leidykla, 1956-1962; 7-9. Vilnius: Mintis, 19661973; 10-15. Vilnius: Mokslas, 1976-1991; 16-17. Vilnius: Mokslo ir enciklopediju leidykla, 1995-1996; 18-19. Vilnius: Mokslo ir enciklopedijų leidybos institutas, 1997-1999.

LKŽe - Lietuvių kalbos žodynas 1-20, 1941-2002, elektroninis variantas, redaktorių kolegija: Gertrūda Naktinienè (vyr. red.), Jonas Paulauskas, Ritutė Petrokienė, 
Vytautas Vitkauskas, Jolanta Zabarskaitė. Vilnius: Lietuvių kalbos institutas, 2005 (atnaujinta versija, 2008). Prieiga internete: http://www.lkz.lt.

LLICh - Lietuviu literatūros istorijos chrestomatija. Feodalizmo epocha. Red. K. Korsakas ir J. Lebedys. Vilnius: Valstybinè grožinès literatūros leidykla, 1957.

LLŽ - Kazimieras Kuzavinis. Lotynų-lietuvių kalbų žodynas. Vilnius: Mokslo ir enciklopedijų leidykla, 1996.

LzŽ - Petrauskas Jonas, Vidugiris Aloyzas. Lazūnų tarmès žodynas. Vilnius: Mokslas, 1985.

Mažiulis Vytautas 1993: Prūsų kalbos etimologijos žodynas 2. Vilnius: Mokslo ir enciklopedijų leidykla.

Mitzka Walter 1919: Ostpreussisches Niederdeutsch nördlich vom Ermland. Marburg:

N. G. Elwert'sche Verlagsbuchhandlung.

MndW - Mittelniederdeutsches Wörterbuch von Dr. Karl Schiller und Dr. August Lübben, 1-6. Photomechanischer Neudruck. Münster in Westf.: Aschendorffsche Verlagsbuchhandlung, 1875-1881.

MŽ - Littauisch-deutsches und Deutsch-littauisches Wörter-Buch, worinn das vom Pfarrer Ruhig zu Walterkehmen ehemals herausgegebene zwar zum Grunde gelegt, aber mit sehr vielen Wörtern, Redens-Arten und Sprüchwörtern zur Hälfte vermehrt und verbessert worden von Christian Gottlieb Mielcke ... Königsberg 1800.

N - Wörterbuch der Littauischen Sprache von G. H. F. Nesselmann. Königsberg: Verlag der Gebrüder Vornträger, 1851.

Natau Otto 1937: Mundart und Siedelung im nordöstlichen Ostpreußen. Königsberg (Pr) und Berlin W. 35: Ost-Europa Verlag.

NSŽ - Naujasis simbolių žodynas. Vilnius, 2002.

PaulW - Deutsches Wörterbuch von Hermann Paul. Halle (Saale): Veb Max Niemeyer Verlag, 1961.

Prel - Die deutschen Lehnwörter im Preussischen und Lautlehre der deutschen Lehnwörter im Litauischen von Dr. Walther Prellwitz. Göttingen: Vandenhoek \& Ruprecht's Verlag, 1891.

PVG - Prūsijos valdžios gromatos, pagraudenimai ir apsakymai lietuviams valstiečiams. Sudarè P. Pakarklis. Vilnius, 1960.

Q - buvusio Karaliaučiaus archyvo rankraštinis (vadinamas A. Krauzès) vokiškai lietuviškas XVII a. žodynas. Msc. 83. Autorius nežinomas. 
$\mathrm{R}$ - Littauisch-Deutsches und Deutsch-Littauisches Lexicon, Worinnen ein hinlänglicher Vorrath an Wörtern und Redensarten, welche sowol in der H. Schrift, als in allerley Handlungen und Verkehr der menschlichen Gesellschaften vorkommen, befindlich ist: Nebst einer historischen Betrachtung der Littauischen Sprache; Wie auch einer gründlichen und erweiterten Grammatick, mit möglichster Sorgfalt, vieljährigem Fleiss, und Beyhülfe der erfahrensten Kenner dieser Sprache gesammelt von Philipp Ruhig ... Königsberg... 1747.

Riemann Erhard 1981-2000: Preussisches Wörterbuch. Deutsche Mundarten Ostund Westpreußens, Band 2, herausgegeben von Erhard Riemann, Band 3-4, hrsg. von Ulrich Tolksdorf, Band 5-6, hrsg. von Reinhard Goltz, Neumünster: Karl Wachholtz Verlag.

Rimkutė Aušra 2012: 1883-1916 metu katekizmu religijos terminai. Daktaro disertacija.

Rubinas Algis 2002: Lietuviu kalbos religine leksika ir jos istorija. Daktaro disertacija.

Sehwers Johannes 1953: Sprachlich-kulturhistorische Untersuchungen vornehmlich über den deutschen Einfluss im Lettischen. Berlin: in Kommission bei Otto Harrassowitz Wiesbaden.

Skardžius Pranas 1931: Die slavischen Lehnwörter im Altlitauischen. Kaunas: Akc. „Spindulio“ b-vès spaustuvè.

Smoczyński Wojciech 2007: Słownik etymologiczny języka litewskiego. Wilno: Uniwersytet Wileński, wydział filologiczny.

ŠvR - Šventasis Raštas. Senasis ir Naujasis testamentas. Antrasis papildytas leidimas. Vertimas iš hebrajų, aramejju ir graikų kalbų. Lietuvos vyskupų konferencija. Vilnius: Katalikų pasaulis, 1999.

ŠVŽŽ - Vanagienè Birutè. Šiaurès vakarų žemaičiu žodynas. Ylakiu, Lenkimu, Mosédžio, Skuodo, Šačių apylinkiu šnektos 1: A-O; 2: P-Ž. Vilnius: Lietuvių kalbos institutas, 2014.

Urbutis Vincas 2009: Baltu etimologijos etiudai 2. Vilnius: Vilniaus universiteto leidykla.

Vasmer Max 1986-1987: Этимологический словарь русского языка 1-4. Москва: Прогресс.

Ziesemer Walther 1975: Preussisches Wörterbuch. Sprache und Volkstum Nordostdeutschlands 1: A-C, 2: D-Fi. Herausgegeben von Ludwig Erich Schmitt. Hildesheim New York: Georg Olms Verlag. 
ZŠŽ - Zanavykų šnektos žodynas 1: Vilnius: Mokslo ir enciklopedijų leidybos institutas, 2003; 2: Mokslo ir enciklopedijų leidybos centras, 2004; 3: Mokslo ir enciklopediju leidybos centras, 2006.

ZtŽ - Vidugiris Aloyzas. Zietelos šnektos žodynas. Vilnius: Mokslo ir enciklopedijų leidybos institutas, 1998.

Kitus sutrumpinimus žr. akademiniame Lietuvių kalbos žodyne (LKŽe).

\title{
Religious, mythological vocabulary: loanwords from Germanic languages
}

\author{
SUMMARY
}

The loanwords of religious and mythological vocabulary were already recorded in the first Lithuanian texts of the $16^{\text {th }}$ century, in particular those of Prussia, Lithuania Minor. The article addresses the religious and mythological vocabulary of Germanic origin or that which came into Lithuanian from Germanic languages from the perspective of semantics and origin. The base word of the Germanism from which it derived is determined; the primary origin of the loanword is identified. The recording of lexemes in the written language dating from the $16^{\text {th }}$ century and their usage in the spoken language and dialects are also presented. The chronology of loanwords is discussed. The loanwords of religious and mythological vocabulary are divided into seven subgroups: church buildings and their parts, administration, environment; church interior, places inside it; objects used in rituals, church items; festivals, rituals; church activities, books, musical instruments; names of persons; mythological vocabulary, names of supernatural beings. It was found that Lithuanian olà is not only used in the meaning of 'a cave, burrow of animals or birds' as defined in the Dictionary of the Lithuanian Language but also as 'a chamber (for burial), crypt, shelter' according to Bretkūnas' Bible. The formations deriving from Germanisms are described as well.

Itteikta 2018 m. rugsèjo 6 d.

NIJOLE் ČEPIENÉ

Lietuviu kalbos institutas

Petro Vileišio g. 5, LT-10308 Vilnius, Lietuva

nijole.cepiene@lki.lt 